Conservation Biology of Freshwater Turtles and Tortoises:

\title{
Carettochelys insculpta Ramsay 1886 - Pig-Nosed Turtle, Fly River Turtle
}

\author{
Arthur Georges ${ }^{1}$, J. Sean Doody ${ }^{1}$, \\ Carla Eisemberg ${ }^{1}$, Erika A. Alacs ${ }^{1}$, and Mark Rose ${ }^{2}$ \\ ${ }^{1}$ Institute for Applied Ecology, University of Canberra, ACT 2601, Australia \\ [georges@aerg.canberra.edu.au;doody@aerg.canberra.edu.au; \\ eisemberg@aerg.canberra.edu.au; alacs@aerg.canberra.edu.au]; \\ ${ }^{2}$ Fauna and Flora International, Jupiter House, 4th Floor, Station Road, \\ Cambridge, CB1 2JD United Kingdom [mark.rose@fauna-flora.org]
}

Summary. - Carettochelys insculpta, the pig-nosed turtle (Family Carettochelyidae), is the sole surviving member of a family of turtles that was widely distributed during the Tertiary. It is restricted to the southern rivers of New Guinea and the rivers of the Northern Territory in Australia. Carettochelys is therefore a distinctive geographic and taxonomic relict and, although locally abundant, it is rare in the sense of being geographically restricted. Moreover, Carettochelys is unique or unusual among turtles in many facets of its morphology, ecology, and behavior. Populations in New Guinea are thought to be declining because of increased exploitation for meat and eggs for both domestic consumption and the international pet trade. This exploitation has been exacerbated in recent times by the introduction of modern technology, principally outboard motors. In addition, clan warfare has ceased, and people have moved from the hinterland to more convenient locations along river banks. Moreover, levels of commercial activity such as logging, mining and exploration for oil, gold, and copper and fishing have increased in recent times, bringing larger human populations, both indigenous and non-indigenous, into closer contact with turtle populations. In Australia, feral animals have posed a threat through widespread trampling of nesting banks and destruction of riparian habitat. Other potential pressures include aggressive pastoral and agricultural practices that push the land in the important catchments beyond capability. Such agricultural development, if not accompanied by appropriate and effective land management, can result in erosion, destruction of riparian vegetation, siltation of water courses, reduction and altered timing and duration of dry season environmental flows, which can lead to gross degradation of riverine habitat as we have seen in the southern states of Australia. Urgent research is required to determine trends in population numbers and levels of exploitation in New Guinea, and to identify and implement management options for the sustainable exploitation of Carettochelys. In Australia, improved knowledge of the distribution of Carettochelys is required, especially the status of populations in the Victoria River, so that the value of the two known major populations in the Daly River and Alligator Rivers region can be adequately assessed. Wet-season habitat requirements, extent of seasonal movements, and requirements of juveniles are unknown, yet this information is needed to gauge the possible impact of proposed or potential development within catchments and to gauge the adequacy of existing reserves for protecting the species.

Distribution. - Australia, Indonesia, Papua New Guinea. Distributed in the southern lowlands of Indonesian Papua and Papua New Guinea, and northwestern Northern Territory, Australia.

Synonymy. - Carettochelys insculptus Ramsay 1886, Carettochelys insculpta, Carettochelys insculpta insculpta, Carettochelys insculpta canni Wells 2002.

SuBSPECIES. - None currently recognized. The subspecific designation by Wells (2002) does not constitute a publication for the purposes of nomenclature, and adequate differentiation of the New Guinean and Australian populations as subspecies has not been presented.

Status. - IUCN 2007 Red List: Vulnerable (VU A1bd) (assessed 2000); CITES: Appendix II; Australian EPBC Act: Not Listed; Northern Territory PWC Act: Near Threatened.

Taxonomy. - Carettochelys insculpta was first described as a new genus and species in 1886 by E.P.Ramsay from an incomplete specimen collected in the Strickland River, a tributary of the Fly River in Papua New Guinea. The circumstances of its collection, by Walter Froggatt and
Jas H. Shaw while on an expedition with the Geographical Society of Australasia, are described by Waite (1905).

Soon after its description, Boulenger (1887) placed Carettochelys in its own family, the Carettochelydidae (emended by Baur [1891b] to Carettochelyidae), and 


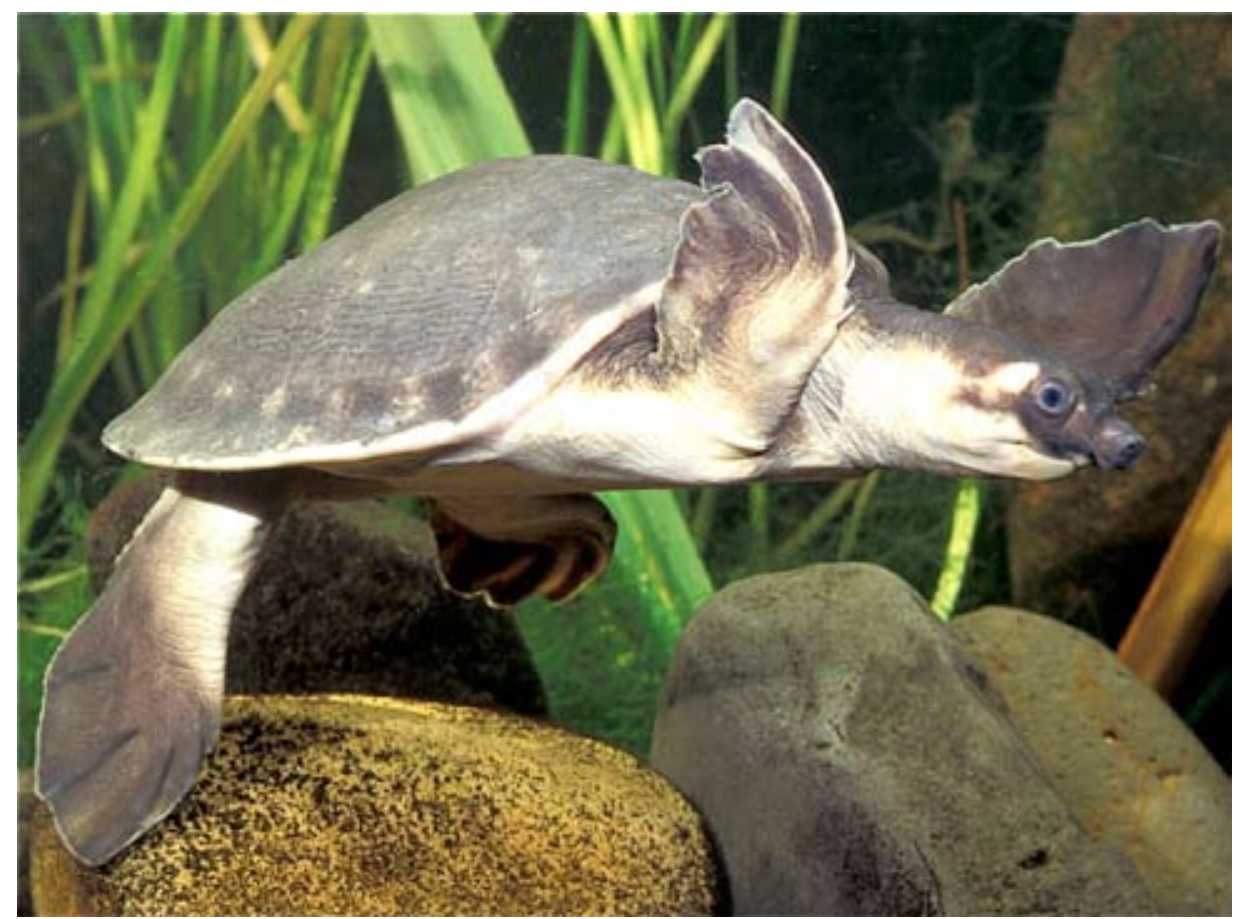

Figure 1. Subadult female Carettochelys insculpta, Daly River, Northern Territory, Australia. Photo by John Cann.

included it among the suborder of side-necked turtles, the Pleurodira. He made this latter decision with some reference to morphological characters, but primarily because at the time, only side-necked turtles were known from Australia and New Guinea. Baur (1891a, b) was opposed to grouping Carettochelys with the side-necked turtles, and called upon Ramsay to release details of the articulation of the cervical vertebrae "to show at once the affinities of this peculiar genus." Unfortunately, the specimen lacked key anatomical elements, the cervical vertebrae, so the matter remained one of considerable debate (Ogilby 1890; Strauch 1890; Vaillant 1894; Boulenger 1898; Gadow 1901; Hay 1908) until the work of Waite (1905) became widely known. He described a more complete specimen from the island of Kiwai at the mouth of the Fly River, and examination of the cervical vertebrae established that Carettochelys properly belongs in the suborder Cryptodira, not the sidenecked Pleurodira.
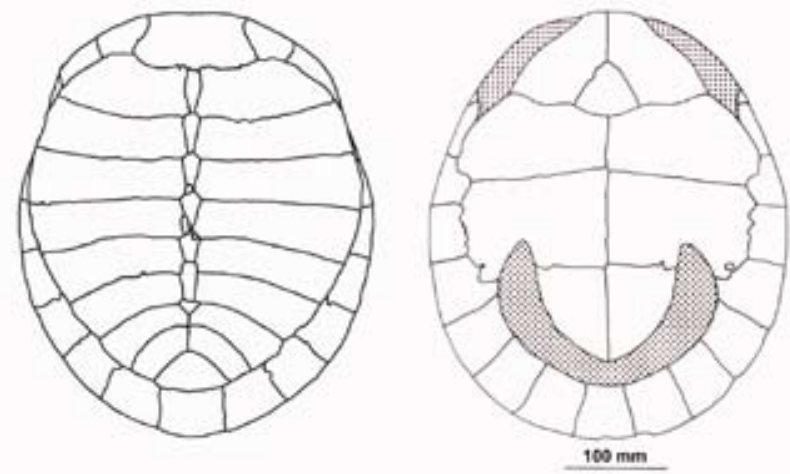

Figure 2. Skeletal structure of the shell of a female Carettochelys insculpta, Daly River,Northern Territory,Australia. Well-developed peripheral bones result in a rigid shell margin.

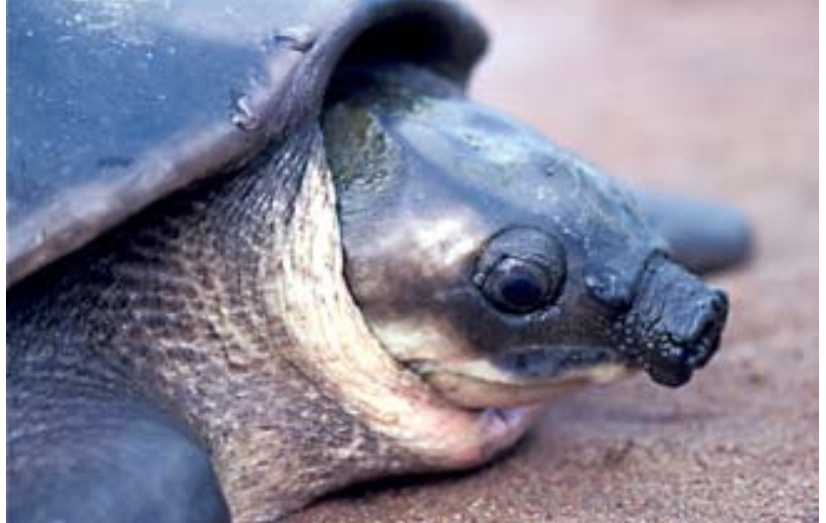

Figure 3. Adult female Carettochelys insculpta, Daly River, Northern Territory, Australia. Photo by Arthur Georges.

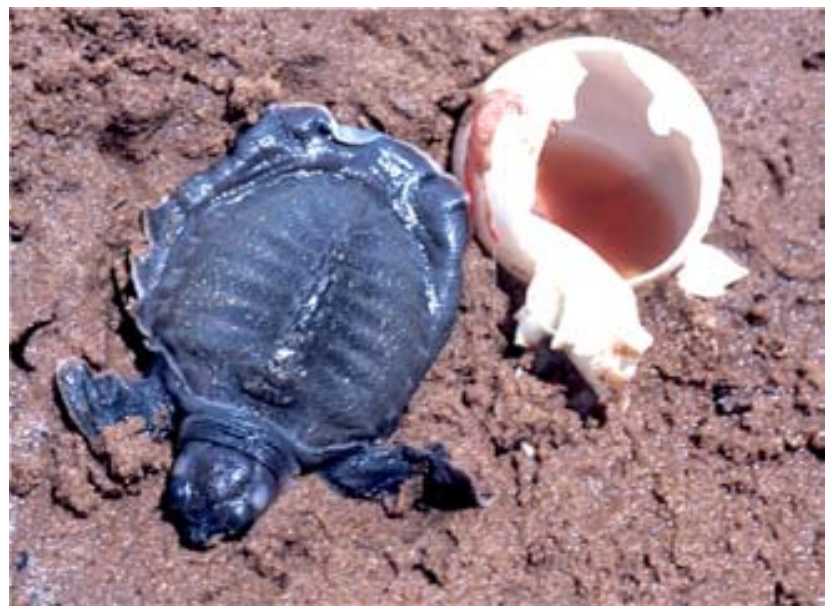

Figure 4. Hatchling Carettochelys insculpta from the Daly River, Northern Territory, Australia. Photo by Arthur Georges. 


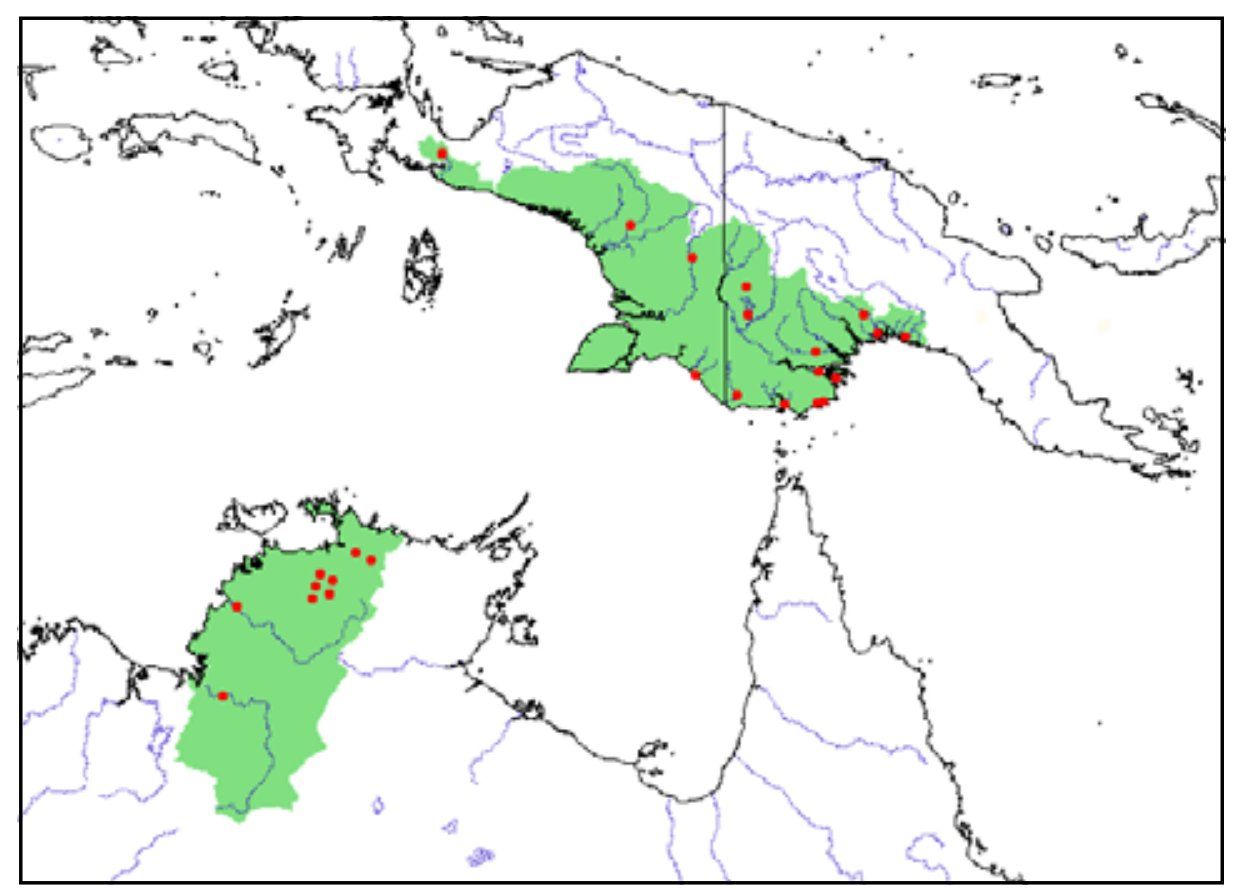

Figure 5. Distribution of Carettochelys insculpta in southern Indonesian Papua and Papua New Guinea, and northwestern Northern Territory in Australia. Red points = museum and literature occurrence records based on published records plus more recent and authors' data; green shading $=$ projected distribution based on GIS-defined hydrologic unit compartments (HUCs) constructed around verified localities and then adding HUCs that connect known point localities in the same watershed or physiographic region, and similar habitats and elevations as verified HUCs (Buhlmann et al., unpubl. data), and adjusted based on authors' data.

The debate on the affinities of Carettochelys continued sporadically, as summarized by Walther (1922), Frair (1985), and Meylan (1988). Current wisdom has it that Carettochelys is the sole surviving member of a family that was widespread in the late Tertiary (Pritchard 1979a), with closest living relatives among the soft-shelled turtles (Trionychidae) (Chen et al. 1980; Frair 1983, 1985; Meylan 1988; Shaffer et al. 1997; Fujita et al. 2004). However, it is sufficiently distinct to warrant retention of the family Carettochelyidae. Its closest relatives among fossil turtles are in the genera Allaeochelys and Chorlakkichelys (Williams 1950; Meylan 1988).

The genus is monotypic and no subspecies are recognized. The New Guinean versus Australian subspecific designations by Wells (2002) (C.i.insculpta and C.i.canni) have gained some currency among aquarists and turtle fanciers but, in our opinion, that paper does not constitute a publication for the purposes of nomenclature and adequate data needed to establish the differentiation of the New Guinea and Australian populations as subspecies has nowhere been presented.

Description. - Original detailed descriptions of the morphology of Carettochelys are provided by Ramsay (1886), Waite (1905), and Walther (1922), and are summarized by Pritchard (1979a) and Georges and Wombey (1993). Carettochelys insculpta is a heavy-bodied turtle, up to $22.0 \mathrm{~kg}$ in weight and $57.0 \mathrm{~cm}$ in carapace length (CL) (Eisemberg, unpubl. data). Body size varies considerably among populations - animals from the Daly River, northern Australia, reach approximately $12 \mathrm{~kg}$, those in the Alligator Rivers region, $16 \mathrm{~kg}$; whereas those of the Kikori region in Papua New Guinea reach $22 \mathrm{~kg}$. Coloration is rich gray, olive-gray, or gray-brown above and white, cream or yellowish below (Fig. 1). The jaws are cream and there is a pale patch behind the eye. The species is cryptodirous, that is, the vertebral column in its neck flexes in the vertical plane when the head is withdrawn. There are no epidermal scutes overlying the shell, which is covered instead with a continuous skin. The plates of the carapace, plastron and skull are covered with small, round rugosities or wavy irregular raised lines between shallow sculptures (hence insculpta $=$ engraved), though these are evident only in preserved specimens. The carapace is relatively deep, with a median keel toward the rear. The peripheral bones are complete and well developed, so there is no flexible shell margin. The plastron, although small, forms a continuous plate without even a median fontanelle (Fig. 2). Several of the plastron elements are not rigidly ossified together, but rather have cartilaginous connections that allow a certain amount of flexibility.

The paddle-shaped forelimbs bear narrow crescentic scales on the rounded anterior edge. Only the first two digits are clawed and the remaining digits are strongly webbed to the tips (Ramsay 1886). The hindlegs are similar, also with two claws, but shorter. The dorsal surface of the tail is covered with a single line of crescent-shaped scales that decrease in size from the base to the tip. Prominent folds of skin extend laterally on each side from the undersurface of the tail across the thigh region and down the hind limbs. The fleshy, truncated, pig-like snout projects forward and downwards (Fig. 3). Its anterior and lateral surfaces are covered with tubercles and it is well-furrowed (Waite 1905, Plate 3.9). Mature males can be distinguished from females 
by the size of the tail, which is larger in males to enable successful copulation, and their smaller adult size. Adult males can be reliably sexed by inserting a small finger into the cloaca to detect the tip of the penis.

Hatchlings from New Guinea weigh $29.6 \pm 0.32 \mathrm{~g}$ on average and have an average CL of $53 \pm 0.25 \mathrm{~mm}$ (Rose, unpubl. data); whereas, the equivalent data for the South Alligator River are $24.7 \pm 0.84 \mathrm{~g}$ and $56.1 \pm 0.91 \mathrm{~mm}$ (Georges and Kennett 1989) and for the Daly River are $20.5 \mathrm{~g}$ and $41.1 \pm 1.22 \mathrm{~mm}$ (Webb et al. 1986). Hatchlings exhibit the full range of shell color variation shown in adults, even within single clutches, and the pale patch behind the eye is present. There may be small light patches on the carapace radiating to the peripherals, and these are more prominent toward the rear of the carapace.

On emergence, hatchlings have well-formed, strong limbs, but an extremely soft plastron and carapace (Fig. 4). The plastron has a deep crease where folding of the body has occurred during incubation. The periphery of the shell comprises loose flaps of skin, which become firm after about one week to form a serrated margin. Hatchlings also have a tuberculate median keel; a poorly defined and transient polygonal outline around each of these tubercules may be homologous to the scute seams of other turtles (Pritchard 1979a). The tubercules are lost as the turtle grows and the median keel is present only on the posterior quarter of the carapace by the time the turtle matures.

Distribution. - The discovery and description of this peculiar species (Ramsay 1886) generated great interest in Europe (Walther 1922), and the species was often specifically sought by explorers and travelers visiting Papua New Guinea and Indonesian Papua (Boulenger 1914; de Rooij 1915, 1922; Schultze-Westrum 1963; Wermuth 1963; Cann 1974). The species was soon recorded from the Strickland (Ramsay 1886; Waite 1905), Fly (Boulenger 1898; Waite 1905), Morehead (Longman 1913), Aramia, Omati (Slater 1961), Binaturi (Rhodin and Rhodin 1977), Purari (Pernetta and Burgin 1980) and Kikori rivers (Rose 1981) of Papua New Guinea (Fig. 5).

It is known in Indonesian Papua from the Setekwa (Boulenger 1914), Heron (de Rooij 1922) and other southern flowing rivers (Cann 1974, 1978, 1980). It was also reported from Lake Jamur (de Rooij 1915), but the specimen consisted of fragments of shell and may have been carried there by natives (de Rooij 1922). Brongersma (1958) reported that Carettochelys was relatively common in the southern flowing rivers of New Guinea. It seems likely that Carettochelys occurs in all major and some of the smaller southern-flowing rivers of Papua New Guinea and Indonesian Papua, but the exact boundaries to its distribution are unknown. No published records of the species exist for rivers east of the Purari, but local native information (Rose, unpubl. data) indicates that its range extends to the Vailala River in the east.

The existence of Carettochelys in northern Australia was not widely known until a specimen from the Daly River was reported in the scientific literature (Peters 1970;
Cogger 2000). Evidence of breeding in Australia dates back to 1918 when eggs from the East Alligator River were lodged with the Victorian Museum (Georges et al. 1989). The presence of Aboriginal rock paintings of Carettochelys (Cann 1980; Dupe 1980; Georges 1987), some dating back more than 7000 years (Chaloupka et al. 1985 and pers. comm.), establishes that the species has long been known to Aboriginal Australians. Nevertheless, the restricted range of Carettochelys (New Guinea and scattered coastal localities in the Northern Territory), the lack of demonstrated subspecific differentiation between the two areas, and the highly aquatic nature and estuarine tendencies of this species, suggest that it is a relatively recent immigrant from New Guinea to Australia (Cogger and Heatwole 1981).

In northern Australia, Carettochelys occurs in the Daly (Cogger 1970; Cann 1972; Webb et al. 1986; Georges 1987), South Alligator (Schodde et al. 1972; Legler 1980, 1982; Press 1986), East Alligator (Georges and Kennett 1989), and Victoria drainages (Cogger 1975, J. Roberts, pers. comm.). There have also been anecdotal reports of the species from the Darwin, Adelaide, McKinlay, and Roper rivers of the Northern Territory (Cann 1972), but these reports need to be substantiated. Capture of a single individual at Roper Bar on the Roper River (J. Bywater, pers. comm.) appears to have been an isolated individual rather than evidence of an established breeding population. Aboriginal people report Carettochelys from the Fitzmaurice River, between the Daly and Victoria rivers. The report of Carettochelys from the Wenlock River on the west coast of Cape York (K. Day, pers. comm. in Webb et al., 1986) cannot be substantiated, and may have resulted from a misidentification. The distribution of Carettochelys in Australia clearly requires further investigation. Earlier reports of animals from the Goomadeer proved to be false, as the people there source their Carettochelys from the East Alligator (Georges, unpubl. data). The East Alligator marks the eastern extent, and the Victoria River the western extent, of the species' range in Australia.

Habitat and Ecology. - In Papua New Guinea, Carettochelys inhabits rivers (including estuarine reaches and river deltas), grassy lagoons, swamps, lakes, and water-holes of the southern lowlands (Liem and Haines 1977; Rose et al. 1982; Georges et al. 2006; Georges et al. 2008). Locals of the Purari region claim that hatchling turtles congregate in the lower delta and feed on vegetation and fruits of mangroves. This is true also of the Kikori River with juveniles found mostly in Kikori delta proper even though adults occur in the main river channels up to $100 \mathrm{~km}$ upstream (Eisemberg, unpubl. data).

In Australia, there are no substantiated reports of Carettochelys occurring in estuarine areas despite extensive surveys of crocodile slides which would almost certainly uncover nesting activity there were it to occur (Press 1986; Georges and Kennett 1989). Rather, the species appears restricted to the seasonally clear, shallow, continuouslyflowing waters of the Daly drainage (Cogger 1970; Cann 1972; Webb et al. 1986) and from lowland and upland 


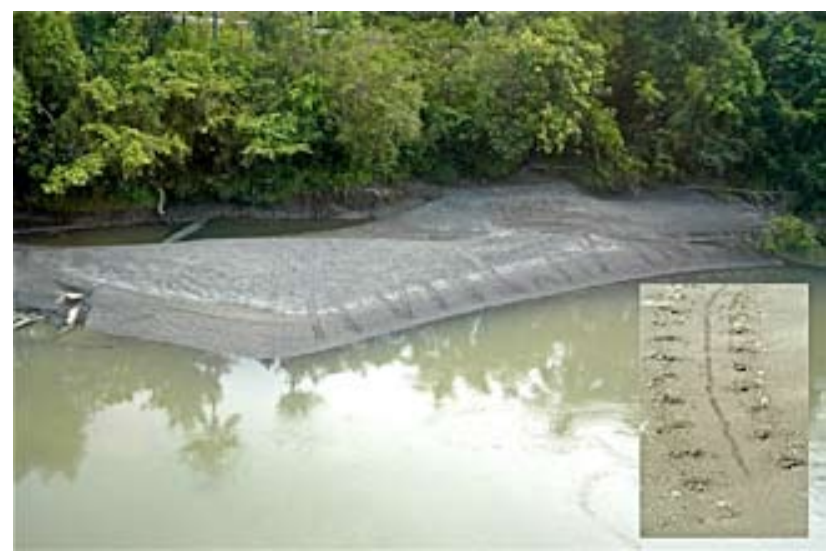

Figure 6. A typical riverine nesting beach for Carettochelys insculpta, Kikori River, Papua New Guinea The distinctive tracks are clearly visible from helicopter. Photos by Arthur Georges.

billabongs and plunge pools of the Alligator Rivers region (Legler 1980, 1982; Press 1986; Georges and Kennett 1989). The preferred dry season habitat in the Alligator Rivers region is typified by Barramundi Creek (Legler 1982) and Pul Pul Billabong (Georges and Kennett 1989). Average depth was approximately $2 \mathrm{~m}$ but there were holes between 3 and $7 \mathrm{~m}$ deep. The substratum was sand and gravel covered with a thin layer of fine silt and litter. Fallen trees and branches, undercut banks, exposed tree roots, and local accumulations of litter provided a diverse range of underwater cover for turtles. The banks of the billabongs

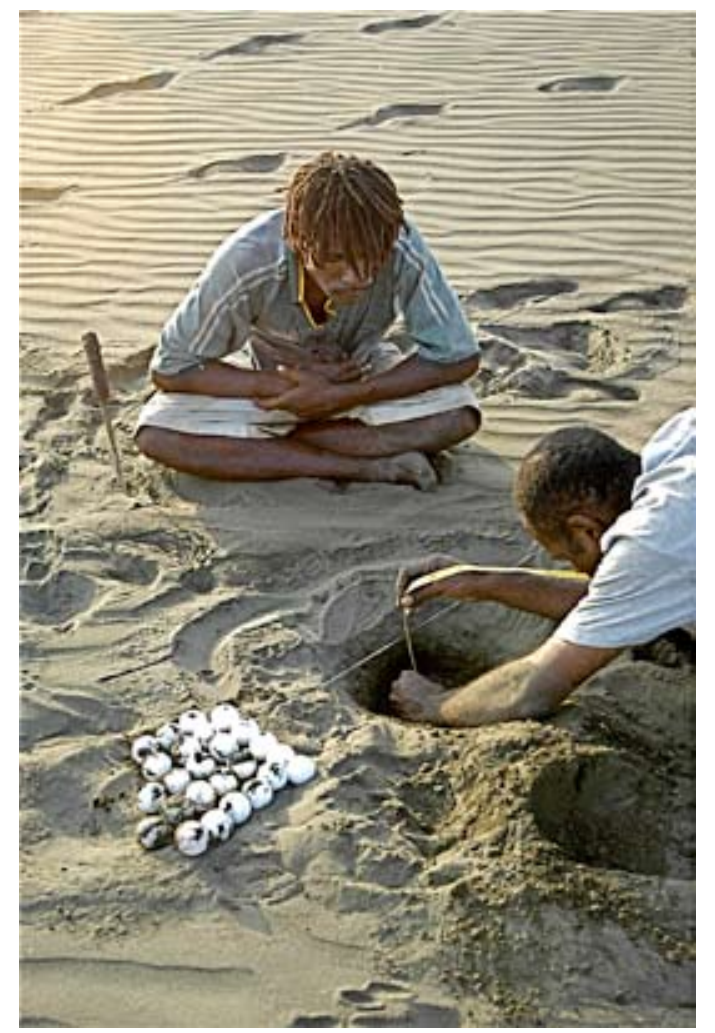

Figure 7. Carettochelys insculpta in Papua New Guinea nests on sand bars in the upper reaches of rivers, but also along the coast (as in this photo) where its nests are periodically inundated by the tides. Photo by Arthur Georges. were covered in a dense broad-leafed forest, including the important turtle food Ficus racemosa. The many small sandbanks adjacent to the water were more than adequate in number and size for nesting. Water flows through the billabongs in all months of most years.

Nesting. - Nesting activity has been reported from the Strickland, Setekwa, Purari, Kikori, Turama, Era, Pai, and Fly rivers of Papua New Guinea (Waite 1905; Boulenger 1914; Pernetta and Burgin 1980; Georges et al. 2008), the southern rivers of Indonesian Papua (Cann 1978, 1980), and the Daly, South Alligator, and East Alligator rivers of northern Australia (Schodde et al. 1972; Georges et al. 1989; Georges and Kennett 1989).

Carettochelys typically nests in clean fine sand adjacent to water (Cann 1978; Pernetta and Burgin 1980; Legler 1982; Webb et al. 1986; Georges et al. 2008) (Fig. 6 ), but nests also in mud, loams, and gravel at some localities (Slater 1961; Cogger 1975, and pers. comm.; Rose et al. 1982; R. Elvish, pers. comm.; Doody et al. 2003b). In Australia, it nests on sand banks adjacent to rivers and billabongs (Webb et al. 1986; Georges and Kennett 1989; Doody et al. 2003c). In New Guinea it also nests adjacent to water in the middle reaches and mouths of rivers, on sandy shores of islands in river deltas, and on coastal marine beaches (Rhodin and Rhodin 1977; Georges et al. 2008) (Fig. 7). On the Daly, nesting beaches were not selected on the basis of their thermal profiles (Doody et al. 2003c). Within beaches nest sites are chosen to balance the competing risk of mortality from premature flooding if the nest is low on the beach with the risk of desiccation and difficulties in constructing nests in the dryer sand of higher locations (Doody et al. 2004).

In New Guinea, Carettochelys nests in the dry season between September and February (Cogger 1975; Cann 1978; Pernetta and Burgin 1980; Eisemberg, unpubl. data). Nesting in the Kikori District spanned 19 weeks in 1981-82. In the 2007-08 season, nesting began on the coast in early October, peaked in November and December and was complete by January (Eisemberg, unpubl. data). Upstream nesting began two months after the coastal nesting had begun, owing to high river levels, and continued sporadically until mid-February. Nesting occurs at night, with the exact timing influenced by the tidal cycle (Eisemberg, unpubl. data).

In Australia, Carettochelys nests late in the dry season, from mid-July to late October on the Daly River (Doody et al. 2003a) and from mid-July to early November in the Alligator Rivers region (Georges and Kennett 1988). Seasonal timing of nesting varies dramatically with the size of the previous wet season and may be related to food acquisition during the wet season: Early nesting follows greater than average wet seasons and later nesting follows lower than average wet seasons (Doody et al. 2003a, 2004). Nesting usually occurs in the first few hours of darkness (centered around $2100 \mathrm{hrs}$ ) (Doody 2002; Doody and Georges 2002) when temperatures at nest depth are near their daily maximum (Georges 1992). 
Gravid females form groups during the nesting season, moving among beaches in search of a nest site (Doody et al. 2003b). Although these groups may contain as many as 12 turtles, usually less than 6 individuals emerge on a given night, and 1-3 actually nest (Doody et al. 2003b). At the end of the season, many sand banks will house up to 20 nests, and others one, two, or none at all. This patchiness is a direct result of the gregarious behavior of the females when nesting. Carettochelys does not to construct a body pit before digging its nest chamber. Instead, the female begins nesting with its hind flippers, which it uses to construct a circular nest chamber about $20 \mathrm{~cm}$ deep. The flipper moves in a circular motion to dig out the sand, a movement that ends with the flipper shaped as a scoop used to carry the sand to the surface. The sand must have sufficient moisture for a chamber to be constructed, which places a limitation on suitable locations for nesting, and in particular, limitations on the height above water in the absence of dry season rains in northern Australia. Minimum air and water temperatures during nesting were 17.5 and $24.6^{\circ} \mathrm{C}$, respectively (Doody et al., unpubl. data). Nesting turtles spent an average of 27 min on a beach (Doody et al., unpubl. data). Relatively short nesting duration in this species may be due to the ease in excavating a chamber in sand, and the close proximity of nesting areas to water (Doody et al., unpubl. data).

There is scant but reliable evidence of multiple clutching based on examination of gonadal structures and identifying sets of corpora lutea or matching counts of corpora lutea to counts of oviductal eggs (Legler 1980 and Rose, unpubl. data). A much more intensive study using field X-ray units (Doody et al. 2003a, 2004) confirmed double clutching, with an inter-nesting period of about 40 days. Surprisingly, though, this study also revealed that females lay two clutches only every second year, a finding of considerable theoretical interest in a species with no substantial migratory cost for reproduction.

Eggs and Clutches. - The eggs are white, hard-shelled, and nearly round (Ramsay 1886) with a mean diameter of $38.7 \pm 1.3 \mathrm{~mm}$ and a mean weight of $33.7 \pm 3.5 \mathrm{~g}$ for eggs from the Daly River (Webb et al. 1986). Eggs from the East Alligator River were somewhat larger (42.0-44.8 mm, n =15) (Georges and Kennett 1989), more in keeping with the size of eggs in New Guinea (Purari River: 38-46 mm, mean $42.9 \mathrm{~mm}, \mathrm{n}=108$, Pernetta and Burgin 1980; Kikori River: means $42.8 \pm 2.3 \mathrm{~mm}, 45.7 \pm 0.7 \mathrm{~g}$, Rose, unpubl. data). Both the ultrastructure (Erben 1970) and the gross morphology of the eggshell and details on egg constituents have been described (Webb et al. 1986).

Clutch sizes range from 7 to 19 (mean $=10$, atypically as few as 3 eggs may be laid) in the Daly River of northern Australia (Webb et al. 1986; Georges 1987; Doody et al. 2003a) and from 7 to 39 in New Guinea (de Rooij 1915; Cann 1978; Pernetta and Burgin 1980; Rose et al. 1982), with an average for the Kikori region of 21 eggs (Eisemberg, unpubl. data). Some of the largest New Guinea clutches may have been laid by more than one female in areas where there was intense nesting activity (Cann
1978). Females with up to 26 hard shelled eggs in their oviducts were found in Kikori (Eisemberg, unpubl. data). In the Daly River, females lay smaller clutches of larger eggs during their second clutch of the year (Doody et al. 2003a). Also in the Daly, after above average wet seasons: 1) clutch masses and clutch sizes are larger; 2) clutch size is influenced by body size; and 3) a trade-off between clutch size and egg size exists (Doody et al. 2003a). These trends are not evident after below average wet seasons (Doody et al. 2003a).

Incubation and Development. - Embryological stages for Carettochelys have been documented and calibrated (as per Yntema 1968), criteria for aging eggs and embryos have been determined (Beggs et al. 2000), and the response of development rate to temperature has been estimated for the full range of temperatures experienced by the embryos in the field (Georges et al. 2004, 2005).

The incubation and hatching biology of Carettochelys is quite unusual. Eggs require $64-74$ days at $30^{\circ} \mathrm{C}$ to develop to a point where hatching is possible (i.e., until yolk internalization) after which they enter embryonic aestivation (Webb et al. 1986). At the onset of aestivation, metabolic rate decreases precipitously and embryonic growth ceases. Yolk is used during diapause at a rate that yielded an estimate of 59 days to yolk exhaustion at 28 to $30^{\circ} \mathrm{C}$ (Webb et al. 1986). The proximal cue for hatching is anoxia, which can be caused by immersion in water or by placing eggs in a nitrogen-only atmosphere (Webb et al. 1986).

In the field, torrential rain that saturates the sand in which the eggs reside or flooding stimulates hatching (Georges 1992), an adaptation that clearly brings hatching into synchronization with the onset of the wet season . Although the mature hatchling can remain in the egg for an estimated 59 days to yolk exhaustion, the stimulus to hatching in the field would normally occur earlier; in 1996-98, hatching occurred on average 17 days (Doody et al. 2001a) after the eggs were developmentally mature (estimated using the modelling of Georges et al. 2004, 2005). Incubation period for 30 natural nests from the Kikori River of Papua New Guinea was between 86 and 102 days (average nest temperature $31.6^{\circ} \mathrm{C}$ ) (Rose, unpubl. data). This presumably included a substantial period of aestivation, which would account for the discrepancy between these findings and those of Webb et al. (1986).

Carettochelys has temperature-dependent sex determination (TSD) (Webb et al. 1986). The constant incubation temperature that produces a 50:50 sex ratio (the pivotal temperature) is $32.0^{\circ} \mathrm{C}$, spanned by a very narrow range, less than $1.0^{\circ} \mathrm{C}$, within which both sexes are produced (Young et al. 2004). Below this range, 100\% males are produced; above it, $100 \%$ females are produced. The period of incubation within which temperature exerts its irreversible influence on sex (the thermosensitive period) spans developmental stages 17-21 (maleness) or 18-21 (femaleness) (Young et al. 2004).

In the Daly River, temperatures vary considerably on a daily cycle of approximately $\pm 6^{\circ} \mathrm{C}$, vary with seasonal 
trends in solar radiation and ambient temperatures, and vary in response to stochastic events, such as rainfall, which depress nest temperatures. Each of these influences complicates the determination of sex in field nests (Georges 1989; Georges et al. 1994, 2004, 2005; Delmas et al. 2008). In particular, the gradients in the magnitude of diel thermal cycles within nests contributes to variation in sex ratio from the top to the bottom of field nests of Carettochelys (Georges 1992), increasing the proportion of nests producing mixed sexes.

Hatching and Hatchlings. - Hatching of Carettochelys is explosive for eggs not subject to partial desiccation (Webb et al. 1986; Doody et al. 2001a). On immersion of eggs, the turtles hatch within minutes, and demonstrate the frenzied activity more usually associated with marine turtle hatchlings as they move to water. Hatching can also be induced by mechanical stimulation, and in laboratory experiments groups of eggs hatched and emerged faster than single eggs treated in the same way, indicating an adaptive function of sibling vibrations (B. Stewart et al., unpubl. data).

Collectively, embryonic aestivation, explosive hatching, and sibling communication are unique adaptations for matching timing of hatching with the onset of the wet season, especially important given the high annual variation in timing of nesting (Doody et al. 2001a, 2004). At hatching, water clarity is dramatically reduced and predation risk of hatchlings likely decreases, although timing emergence with the onset of the wet season may also maximize food availability for hatchlings (Webb et al. 1986; Doody et al. 2001a).

In Papua New Guinea, hatchlings also may have to contend with osmoregulation challenges as many nests are oviposited on coastal beaches or even isolated offshore sandbars where salinity of the surrounding water can reach 21 ppt (Eisemberg, unpubl. data). Notwithstanding the influence of specific cues for synchronized hatching, hatchlings emerge from the nest as nest temperatures are decreasing, at night, typically around midnight early in the season but earlier in the night and at lower temperatures as the season progresses (Doody et al. 2001a).

In the Daly River, first clutches of the season usually yield males, whereas second clutches usually produce females, with some mixed nests in each (Doody et al. 2004). Thus, a strong temporal effect determines hatchling sex, while spatial effects (i.e., nest site choice, nest depth) have the potential to affect the sex of hatchlings to emerge from nests with intermediate laying dates (Doody et al. 2004). This pattern, coupled with marked annual variation in timing of nesting, leads to a strong effect of year on hatchling sex ratios. In years with late nesting hatchling sex ratios are strongly female biased (ca. 2:1), while early nesting leads to more balanced sex ratios (Doody et al. 2004). Thus, the duration and intensity of the previous wet season (or possibly the previous two wet seasons, because it takes two years for females to complete vitellogenesis) determines hatchling sex ratios (Doody et al. 2003a, 2004).
A caveat is that flood mortality of mostly-female nests in years with late nesting can counter the hatchling sex ratio bias (Doody et al. 2004). Adult sex ratios in the Daly River were 3:2 in favor of females (Heaphy 1990; Doody 2002).

Nest mortality on the Daly River occurs mainly through predation and flood mortality, although other minor sources exist, such as trampling by feral buffalos. Nest predation by the yellow-spotted monitor lizard (Varanus panoptes) averaged nearly 20\% during 1996-98 (11 to 25\%) (Doody et al. 2004). However, the arrival of invasive cane toads (Bufo marinus) in 2003 decimated populations of V. panoptes (Doody et al. 2007), leading to no predation on Carettochelys nests in 2004 (Doody et al. 2006). Daly River Carettochelys aggregate their nests, but probability of predation was not influenced by the number of nests on a beach (Doody et al. 2003b). Other predators of Carettochelys eggs in northern Australia include the monitor V.mertensi (Doody 2002) and humans (Press 1986; Georges and Kennett 1988). Nest mortality due to flooding on the Daly River was $20 \%$ when turtles nested late after a below average wet season (Doody et al. 2004). Most nests destroyed by floods were laid at low elevations and had not completed development by the time flooding began (Doody et al. 2004). Finally, 20\% of nests experienced complete embryonic failure due to intrinsic factors such as infertility and developmental problems (Doody et al. 2004).

In the Kikori region of Papua New Guinea, the main causes of nest mortality are from human harvests, predation by monitor lizards (Varanus sp.) and river flooding (Eisemberg, unpubl. data). Although there are some reports from other areas (Cann 1974; Pernetta and Burgin 1980; Rose et al. 1982; Georges et al. 2008), there is little published information on natural levels of egg survivorship elsewhere. In one season at one location, on a island off the coast of the Kikori delta, only $8 \%$ of 60 nests survived human harvest and tidal flooding (Eisemberg, unpubl. data).

Diet. - Carettochelys is omnivorous, but tends more toward herbivory than omnivory (Rose et al. 1982; Heaphy 1990; Welsh 1999). In the Gulf Province of Papua New Guinea it feeds principally on the unripe fruits, leaves, and stems of the mangrove and upstream species of Sonneratia spp., possibly by cropping the fruits from the vegetation at high tide or catching them as they fall in the river (Rose, unpubl. data; Eisemberg, unpubl. data). Fruits from Xylocarpus sp., Nypa fructicous, Canorium indicum, Antrocarpus incisor, and the wild pit-pit Sachhorum robistum are also eaten. Animal foods included the molluscs Batissa violocea, Nerita sp., and Centhidea sp., and the crustacean Siyellu serrata.

In the Alligator River system of Australia, Carettochelys feeds on the leaves, fruits, and flowers of riparian vegetation, especially the fig Ficus racemosa, the bush apple Syzygium forte, and Pandanus aquaticus (Schodde et al. 1972; Legler 1982; Georges and Kennett 1989). Other foods include aquatic insect larvae, crustacea, mollusca, fishes, and mammals (possibly eaten as carrion), 
and aquatic plants such as algae, Vallisneria sp. and Najas tenuifolia (Cogger 1970; Schodde et al. 1972; Legler 1982; Georges et al. 1989; Georges and Kennett 1989). In the Daly River, during the dry season Carettochelys eats mainly ribbonweed (Vallisnaria sp.), but also eats small amounts of green algae, snails, and figs (Heaphy 1990; Welsh 1999). The wide range of foods eaten provides great scope for opportunism, and the diet varies greatly with the foods available from locality to locality. The low frequency of reproduction, lack of fat deposits in the dry season, and relatively small body size of Daly River Carettochelys is likely attributable to the low energy content of Vallisneria (Doody et al. 2003a; Davies 2005).

Growth. - Very little is known of the growth rates and demography of Carettochelys, as long-term markrecapture has not been a focus of work to date, and there are challenges in permanently marking the animals. Female Carettochelys from the Daly River mature at around $82 \%$ of maximum size (smallest gravid turtle, $\mathrm{CL}=38.0 \mathrm{~cm}, \mathrm{PL}$ $=30.5 \mathrm{~cm}$, mass $=5.9 \mathrm{~kg}$ ) (Doody et al. 2003a) at around $77 \%$ of maximum size in the Kikori (smallest gravid turtle, $\mathrm{CL}=41.0 \mathrm{~cm}, \mathrm{PL}=40.7 \mathrm{~cm}$, mass $=19.3 \mathrm{~kg}$, Eisemberg, unpubl. data). There are no data on the size at onset of maturity for males, or the age at maturity of either sex, but males are smaller than females and so presumably mature at smaller sizes (Doody 2002). Lack of information on growth rates, age at onset of maturity, age structure, rates of recruitment and mortality, and in particular, details of the "lost years" between hatching and adulthood, promise to be major impediments to population modeling to inform management.

Activity, Movements, and Dispersal. - In the Daly River, Carettochelys is not nocturnal, as previously thought (Heaphy 1990), but is active day and night (Davies 2005). Prolonged activity may reflect the need to maximize food intake in an energy-limited system (Doody et al. 2003a; Davies 2005).

The home ranges of Daly River Carettochelys are among the largest known for freshwater turtles, extending up to 10 linear $\mathrm{km}$ of river channel during the dry season (Doody et al. 2002). Females are more active, move further, and occupy larger homes ranges than males (mean 8.3 linear km vs. $3.2 \mathrm{~km}$; Doody et al., 2002), though this difference in movement reduces after the females have laid their eggs (Doody et al. 2002). Males also moved more when females were gravid than at other times. During the wet season, turtles moved from the main channel into small creeks, billabongs, and flooded riparian areas near their dry season home ranges rather than migrating to coastal floodplains (Doody et al. 2002).

In the Daly, most turtles use localized thermal springs emanating from the river bottom in late autumn, winter, and early spring to elevate body temperatures by up to $5^{\circ} \mathrm{C}$ (Doody et al. 2001b; Davies 2005). These springs form a focus for activity, though the proximity of food patches and nesting beaches are important also (Doody et al. 2002). Females basked on thermal springs more than did males, but gravid females thermoregulated similarly to non-gravid females (Davies 2005). Thermal spring basking may enhance digestion and follicular growth. Turtles in a stretch of river with springs nested earlier than those in a stretch with no springs (Doody et al. 2001b).

Little is known of the home range and movements of turtles in the Kikori region of Papua New Guinea, but the extensive feeding grounds comprising the Kikori Delta are some distance from the nesting areas on the coast and in the upper tidal reaches of the Kikori River (Georges et al. 2008). Presumably females migrate considerable distances during the nesting season, and juvenile turtles move back to the delta and its flooded forests from the nesting areas soon after hatching. In the Kikori, turtles are presented with a dichotomy in nesting opportunity (nest on the coast, or upstream; Georges et al. 2008). It is not known if the individual turtles use both localities or if some females consistently nest upstream and others consistently on the coast. Natal homing might come into play, effectively creating two stocks. These are questions that require further investigation.

There are no records of long range movements of Carettochelys. The specimen collected from Roper Bar in the Roper River, where there are no established populations, presumably was a long-range migrant from the west. There is no evidence of contemporary exchange of specimens between Australia and New Guinea. The extent of movement within well connected regions such as the rivers discharging into the Gulf of Papua is unknown, yet this information has important implications for management.

Population Status. - Carettochelys insculpta was long considered one of the rarest turtles in the world (Rose et al. 1982) but it is not certain whether this reputation reflected its remote distribution or also low population densities (Pritchard 1979a). In fact many considered it to be fairly common where it occurs in both Australia and New Guinea (Brongersma 1958; Slater 1961; Cann 1974, 1980; Press 1986; Georges et al. 2007b). It has been reported as rare in Indonesian Papua, with a sparse and limited distribution (Anonymous 1978), but this conflicts with the observations of Cann $(1974,1978,1980)$ who found it to be common there.

Georges and Kennett (1989) found Carettochelys to be widespread between the tidal reaches and the headwaters of the South Alligator River in Australia, and that high densities may be present in the upper reaches during the dry season $(33.8 \pm 11.3$ turtles per ha in small discrete ponds on the main channel). These estimates are so high as to be almost certainly aggregations in spring-fed dry season refugia rather than normal estimates of sustainable population density. Over 250 specimens have been captured in a $20 \mathrm{~km}$ stretch of the Daly River over a 3-year period (Doody, unpubl. data). More than 100 specimens were harvested between September 2007 and February 2008 in the Kikori River District of Papua New Guinea (Gulf Province) (Eisemberg, unpubl data), attesting both to its continued persistence in reasonable densities and 
a continued and presumably unsustainable level of adult harvest. Populations of Carettochelys are reported to have been severely depleted in the last few decades, and the populations in the Western Province appear to be declining (Rose 1981; Rose et al. 1982). Regardless of high densities in some areas within its range, Carettochelys is both a geographic and a taxonomic relict species (sensu Simpson 1944) and is rare in the sense of being geographically restricted. Locally abundant species with restricted ranges are possibly more vulnerable than scarce but widely distributed species (Rabinowitz 1981).

Threats to Survival. - The major threats to pig-nosed turtles include wildlife trade for the international pet market, indigenous harvest for local consumption, and habitat destruction.

Wildife Trade. - The pig-nosed turtle has been identified by the World Wide Fund for Nature (WWF) as one of the ten most wanted species for the global illegal commerce of wildlife. In New Guinea (combining Indonesian Papua and Papua New Guinea) Carettochelys is the most exploited turtle (van Dijk et al. 2000). It is heavily exploited for food by local peoples (see indigenous harvest section) and to supply the international pet industry where demand by hobbyists is extremely high because of its unique appearance. Despite the protected status of Carettochelys, in the late 1990s approximately 1,500,000 to 2,000,000 eggs per year were illegally collected from Indonesian Papua. Over 500,000 eggs were estimated by local authorities to be collected from the Flinshap River alone during 1998 (Maturbongs 2001). The vast majority of the eggs were incubated and the hatchlings shipped to Jakarta, Ujung, Pandang, Surabaya, or Denpasar where they were illegally exported to Taiwan, China, or Singapore (Samedi and Iskandar 2000; Samedi and Irvan 2002). Illegal trade along the Papua New Guinea and Indonesian Papua border has also been documented with villagers stockpiling specimens to sell to traders from Merauke (Rhodin and Genorupa 2000). In 1999, hatchlings were sold for USD $\$ 1.10$ to $\$ 21.69$ in Senggo and Antsy with a price increase to USD \$3.37 each in Merauke and USD \$6.74 to \$7.87 in Surabaya (Maturbongs 2001).

Pig-nosed turtles continue to be traded illegally and have recently been reported for sale in Indonesia, Singapore, Japan, Thailand, China, USA, and Europe. In Indonesia, Jakarta is the hub for illegal trade of wildlife, with pig-nosed turtles observed for sale between August to November 2004 (Shepherd and Nijman 2007). Stock turnover of Carettochelys in Jakarta markets is high and they are sold for USD $\$ 18$ to $\$ 104$ (Shepherd and Nijman 2007). Most pig-nosed turtles that are smuggled into Jakarta are not sold locally but exported to other international destinations. In February 2004, three separate shipments destined for Japan containing 100, 390, and 309 pig-nosed turtles, respectively, were seized at Jakarta's International Airport (Fidrus 2004). A smuggling attempt of 7275 pignosed turtles was foiled in August 2005 by the East Java Natural Resources Conservation Body (BKSDA) during a raid in Tanjung Perak seaport, Merauke. The turtles were found inside several drums inside a boat crew room with 145 already dead from lack of oxygen (Harsaputra 2005).

Like Jakarta, Bangkok (Thailand) is a well known port for illegal smuggling of wildlife. Surveys of pet shops in the Chatuchak market in Bangkok conducted for one day each in January and August 2006 and in April 2007 found a few pig-nosed turtles for sale (Shepherd and Nijman 2007). In Taipei during 1995, several Carettochelys were found for sale as pets in the local markets (Chen et al. 2000). The numbers sold locally are small compared to those that are smuggled to other countries through Thai airports and seaports. An animal dealer reported to a TRAFFIC researcher that it is common practice to bind the turtles' heads and legs with tape to keep the animal in position because movement can be detected by the X-ray machines used in the airport (Shepherd and Nijman 2007). In January 2007, authorities in Thailand seized 1043 Carettochelys that were packed in a suitcase in a public bus headed to Bangkok destined for sale on the local markets or for illegal export (AFP 2007).

Illegal imports of pig-nosed turtles into Singapore are frequent. In 2007, seven of 27 pet shops surveyed in Singapore were selling pig-nosed turtles for prices of USD $\$ 18$ to $\$ 75$ each. Shopkeepers reported that the majority of hatchlings were sold to young people that rear them to maturity and sell the adults for USD $\$ 1500$ to $\$ 2000$ on the international market (Goh and O'Riordan 2007). From Singapore turtles are smuggled to the US and Japan. In January 2003, a package from Singapore to Florida was intercepted by U.S. Customs containing 198 Carettochelys, 25 Geochelone elegans (Indian star tortoise) and three monitor lizards (U.S. Fish and Wildlife Service 2003). In Japan Carettochelys is a common pet; ca. $59.4 \%$ of 32 shops surveyed in 2002 located in Tokyo, Chubu, and Kansia had Carettochelys for sale as pets (Kameoka and Kiyono 2005). The demand in China for Carettochelys is also high with hundreds of turtles observed in a survey of 5 pet shops in Hong Kong between 30 October 2000 and 13 October 2001 (Ades 2002). In Europe, pig-nosed turtles have been openly advertised for sale in reptile hobbyist magazines (Auliya 2003). A comprehensive assessment of the impacts of the international illegal trade of the pig-nosed turtle Carettochelys has not been conducted, but the scale of the trade as indicated by market surveys and seizures suggest that it is currently not sustainable. As a result of this international trade, Carettochelys was recently listed by CITES on its Appendix II.

Indigenous Harvest. - Carettochelys insculpta is highly prized as a food item by the indigenous peoples within its range both in Australia and New Guinea (Schultze-Westrum 1963; Cann 1980; Press 1986; Georges et al. 2007a, 2008) and is important to the subsistence economies of several Papuan communities (Pernetta and Burgin 1980). Both the adults and their eggs are collected, consumed, and sold throughout its range in Papua New Guinea. In Kikori Market alone, over 5000 eggs were 
sold between October 1980 and February 1981 (Rose et al. 1982). In the following year, over 20,000 eggs were collected and consumed in Kikori and three surrounding villages (Rose, unpubl. data). In the breeding season, villagers collect female turtles and their eggs when they come to shore to nest, or they locate nests by systematically prodding sand banks with a bush knife, stick, or spear. In some areas, pit-traps (Georges et al. 2006) are checked each day for nesting turtles that have fallen in the previous night (Rose et al. 1982). Out of season, turtles are caught by hand from boats in shallow water and swamps, often with the aid of a diving mask ("glass"), or on lines baited with crab or de-shelled mussels (Rose et al. 1982) and in basket traps (Schultze-Westrum 1963).

In northern Australia, turtles are regularly eaten by Aborigines, and pig-nosed turtles are favored by some for their size and flavor (Cann 1980; Press 1986). Traditionally, aboriginal men climbed trees on the banks of billabongs and speared the turtles when they surfaced (Georges 1987). Alternatively, Carettochelys could be hunted by diving on top of them from the bank or by waiting quietly in the water while others herded the turtles in. Today, however, they are mainly caught by fishing (Cann 1972; Georges 1987). There are no reports of Australian Aborigines harvesting the eggs of Carettochelys in Kakadu National Park, but they are occasionally collected as food by Aboriginal people of the Daly River (Wagiman and Naiyu).

Rose et al. (1982) considered that traditional hunting of turtles and harvesting of eggs in southern New Guinea was the principal threat to the species. Stereotyped nesting habits render Carettochelys (like sea turtles) extremely susceptible to over-exploitation (Fig. 8). Levels of exploitation in the Gulf and Western Provinces have been exacerbated in recent times by the introduction of modern technology, principally outboard motors, and since clan warfare has ceased, people have moved from the hinterland to more convenient locations along river banks. Populations of Carettochelys in New Guinea have been reported to have declined sharply in the past several decades (Rose et al. 1982). Contemporary pressure on these populations would be much greater if fuel were more readily available and affordable. During the nesting season from September 2007 to February 2008, in the Kikori region only $15 \%$ of locals who hunted the turtles used outboard motors citing the price of petrol and outboard oil as prohibitive (Eisemberg, unpubl. data). This could change rapidly as communities close to major developments move from a subsistence economy to a cash economy, and as new infrastructure opens access to more lucrative markets for sale of turtle products.

There are few data on levels of exploitation in Australia. Georges and Kennett (1988) reported an annual harvest of 19 turtles by two Aboriginal families at Nourlangie Camp, and the Wagiman Aboriginal people record their dry season harvest of turtles from the Daly River each year (Doody, pers. comm.) but without adequate data on population numbers and recruitment, it is not known whether this harvest activity exceeds a sustainable yield.

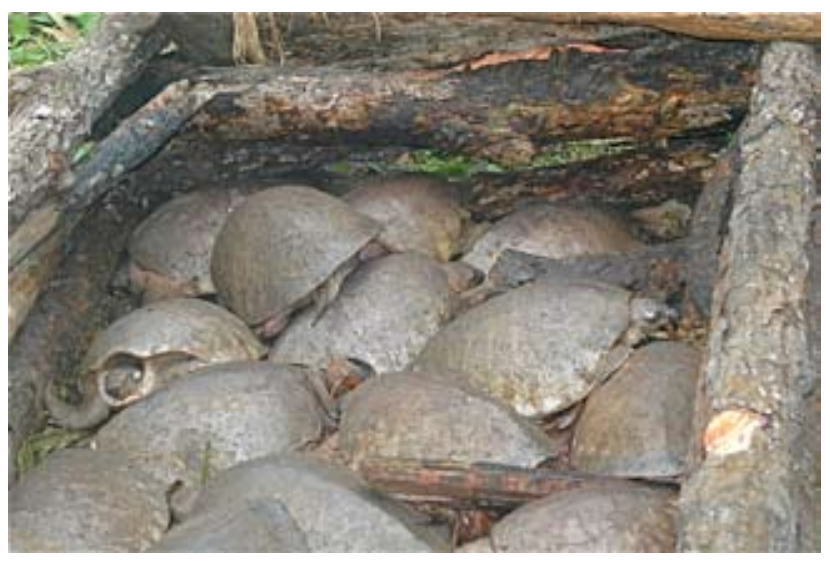

Figure 8. Stereotyped nesting habits render Carettochelys (like sea turtles) extremely susceptible to over-exploitation. Shown here are 24 adult nesting turtles harvested immediately after high tide on one night on one coastal beach in Papua New Guinea in 2007. The animals were flipped on their backs by the hunter who returned later to collect them and return them to camp where they were held in a makeshift enclosure until slaughter. The meat fed many families. Photo by Carla Eisemberg.

Habitat Destruction. - Agricultural and pastoral activities in the catchments of the Daly drainage have the potential to seriously impact Carettochelys populations where stocking rates are high, the riparian vegetation is cleared, or the land is pushed beyond its capability, with subsequent erosion and siltation of water courses. Tropical rivers of northern Australia discharge approximately $70 \%$ of Australia's available freshwater, so there is considerable pressure to develop these water resources for agricultural use, largely for irrigation. Governments now recognize that huge mistakes have been made in southern Australia where many key irrigation systems are now degraded or degrading, with deterioration in the biota associated with major river systems and the ecosystem services that are prohibitively expensive to replace technologically. While nobody wants to see these mistakes repeated in the north, there is little confidence that society has found the way to balance the commercial imperative for short-term benefit against the long-term market imperative for sustainable economic growth and society's concern to sustain non-consumptive values of the environment for future generations.

The Daly catchment is a particular focus for agricultural development. Plans currently under development include the possibility of drawing from dry-season river-flow, via surface and ground-water offtake, in support of agriculture. The resultant fragmentation of what is now a year-round flowing system, increases in sediment load and decreases in water clarity, and alteration of water temperatures, could have a major impact on Carettochelys (Georges et al. 2002; Erskine et al. 2003). Fragmentation of the river during the dry season would constrain turtle home ranges under even moderate reductions in dry-season flow, and limit accessibility to nesting banks. Increased turbidity would have a dramatic effect on Vallisneria, a mainstay of the diet of Carettochelys during the dry season in the Daly River. A relatively minor shift in nesting dates in response to water 
temperatures (should flow cease altogether and pools draw down) could have a major impact on offspring sex ratios (Georges et al. 2002) which respond to soil temperatures, or on timing of hatching in relation to the onset of the wet season.

Feral water buffalo once posed a threat to pig-nosed turtles and their habitat in the Alligator Rivers region of northern Australia. The sand banks used for nesting by Carettochelys were also used as easy access to water and as resting places at night by water buffalo. This led Archie Carr to comment in a letter to Pritchard (1979b) that Carettochelys may have become much more restricted in its Australian distribution since the introduction of water buffalo.

A survey of Carettochelys nesting conducted in 1987 (Georges and Kennett 1988) bore this out. Buffalo densities in Goodparla Station (now part of Kakadu National Park) were so high that all potential nesting banks in the survey were heavily trampled. Such trampling is known to destroy nests both in Kakadu (Georges and Kennett 1989) and on the Daly River (Georges, unpubl. data). Water buffalo also destroy the riparian vegetation upon which the turtles depend in the dry season for food, by foraging on young plants and structurally destroying the banks of billabongs. Buffalo wallows break through the upper stable layers of the soil, exposing the water mobile layers beneath, causing very extensive and widespread erosion that can lead to total denudation of the riparian zones (Georges and Kennett 1989). While this may initially benefit Carettochelys by increasing underwater cover afforded by fallen trees, branches, and litter, it can only have long-term deleterious effects on the turtle populations which rely heavily on allocthonous inputs during the dry season (Georges and Kennett 1989).

Fortunately, buffalo numbers have been drastically reduced within Kakadu National Park, and across the Northern Territory, as part of on-going management for nature conservation and disease control under the Brucellosis and Tuberculosis Eradication Campaign (BTEC) (Freeland and Boulton 1990). Carettochelys presumably will be a beneficiary of this action, but without monitoring, it has been difficult to quantify these collateral benefits of feral animal control. The days of uncontrolled feral populations of large herbivores within the range of Carettochelys are probably past, but the lessons of the past suggest that unlimited access of stock to sensitive riparian zones and waterbodies of conservation value needs to be kept on the agenda.

Mining activity in sensitive areas such as Kakadu National Park in Australia or the Fly River in New Guinea, may pose a potential threat to the environment and the fauna that depends upon it (Dames and Moore International 1987; Georges and Kennett 1988). Exploration and mining for gold by chemical extraction was once planned for the headwaters of the South Alligator River, in the region identified as providing important refuge ponds for Carettochelys in the dry season (Georges and Kennett 1988; Georges and
Kennett 1989). Contaminated rainwater run-off, accidental discharges from the tailings dam or treatment plant, or accidental spillage of hazardous industrial chemicals at stream or tributary crossings during transport to the mill site are all potential sources of destructive pollution. Demands on water for mining operations may deplete the water table and reduce water levels in the shallow billabongs used by Carettochelys as dry-season refuges. Upgrading river crossings and causeways, if not sensitively constructed, may restrict the free movement of turtles during the early dry season. Carettochelys is easily caught on baited lines (Cogger 1970; Georges and Kennett 1988) and populations may be negatively impacted by bringing larger human populations into contact with turtle populations. In Papua New Guinea, mining, forestry, and other commercial operations organized by domestic and foreign interests will increase river traffic, which in turn may increase the number of turtles and eggs taken. However, this issue is complex, as such commercial activity shifts the economic focus of indigenous communities from subsistence to cash, with less than predictable consequences for the efforts they put into hunting turtles and gathering their eggs for consumption and sale.

Mining is no longer a current pressure on protected areas containing substantial Carettochelys populations in Australia, though the deposits remain a future commercial attraction. Standards and levels of scrutiny of mining operations are rising. Mining operations are often spatially quite restricted, and there is great potential for coincident investment in remedial environmental works, that go beyond the direct scope of the mining operation, to more than offset the impacts of the mining activity. There have been successes and failures (for example, standards for the protection of the environment by the Ok Tedi mining operation have been questioned and evidence of widespread environmental damage is mounting). However, great potential exists in Papua New Guinea and Australia for net conservation benefit through collaboration between mining companies and conservation agencies.

Conservation Measures Taken. - Internationally, Carettochelys has been listed in the IUCN Red List of Threatened Species since its inception, first as Insufficiently Known (Rose et al. 1982) but more recently as Vulnerable (Baillie and Groombridge 1996; IUCN 2007) because of suspected dramatic declines over most of its range. The species is listed in Appendix II of CITES following nominations in 2005 from the USA and Indonesia. The IUCN/SSC Tortoise and Freshwater Turtle Specialist Group assigned the species an Action Plan Rating of 1 (known threatened species in need of specific conservation measures) (Stubbs 1989).

In Australia, Carettochelys benefits from State and Federal legislation that controls the exploitation of native fauna by both indigenous and non-indigenous Australians. It is protected by the National Parks and Wildlife Conservation Act 1975 in Kakadu National Park and elsewhere in the Northern Territory by the Territory Parks and Wildlife 
Conservation Act 1982 (R. Jenkins, pers. comm.). The species has been listed in the Northern Territory as Near Threatened under their Parks and Wildlife Conservation Act (NTPC 2005). Export from Australia is prohibited under the Wildlife Protection (Regulation of Exports and Imports) Act 1982. However, such legislation is limited in its value from a conservation perspective, because it does not protect the species from ongoing habitat destruction or modification. Australia has the Environment Protection and Biodiversity Conservation Act of 1999 (EPBC Act) to provide a legal framework to protect and manage nationally and internationally important flora, fauna, ecological communities and heritage places-defined in the Act as matters of national environmental significance.

The EPBC Act has the potential to bring national scrutiny to developmental proposals, but only threatened species or communities listed under the EPBC Act trigger this scrutiny. While the EPBC Act has the potential to take broader national and international perspective on the conservation of Carettochelys and its habitat than is possible at the State level, a recent bid to have the species listed nationally as Vulnerable failed (TSSC 2005). It appears that proposed land clearing and water resource development must have a demonstrable impact on domestic populations of Carettochelys before such a species, listed as Vulnerable internationally, can be factored into national regulatory instruments designed to bring balance to decisions on conservation and development.

In Papua New Guinea (PNG), domestic exploitation of Carettochelys, a traditional food source, is largely unregulated, and lack of infrastructure severely limits international trade, whether legal or illegal. Export of wildlife is governed by the International Trade (Fauna and Flora) Act of 1979 administered by the Department of Environment and Conservation and policed by PNG customs. As in Australia, export of Carettochelys from PNG for commercial purposes is effectively prohibited, though there is some illegal trade across the border with Indonesia (Rhodin and Genorupa 2000).

In Indonesian Papua, domestic exploitation is also traditional, and largely unregulated. However, export of Carettochelys from Indonesia is permitted, under a quota set by the Indonesian CITES Management Authority, where the animals are captive-bred. This provision is loosely interpreted to include animals incubated and hatched in captivity from wild-collected eggs (Samedi and Iskandar 2000). Recently intensified egg collection, to a large part driven by the aim to supply hatchlings to the international pet trade, is threatening populations of the species in Indonesian Papua (Maturbongs 2001).

The provision of national parks and reserves would appear to be an appropriate response to ensure the conservation of a species that is locally abundant within a limited distribution. In Australia, Kakadu National Park affords the species considerable protection, and ongoing feral animal control continues to deliver the benefits of the BTEC feral animal eradication program. However, the park is currently a compromise between conservation, mining, recreation, and other interests, and there are continual, albeit intermittent, moves to annex important regions for mining. Until recently, Australia's most substantial populations of Carettochelys, in the middle reaches of the Daly River, lay outside formal protected areas. Fortunately, there have been a number of recent improvements, driven by concern for the health of the Daly River more generally (Blanch et al. 2005). The riparian vegetation of the Daly River from the Daly River Township to the King River has been listed as part of the National Estate in recognition of its conservation and cultural value within the overall catchment. A small protected area on the Flora River (Flora River Nature Park), a tributary of the Daly, has breeding populations of Carettochelys, and substantial segments of the Daly and Douglas River have been declared Conservation Areas.

In Papua New Guinea, the species has been recorded in Tonda Wildlife Management Area in the Western Province (Liem 1977; Herington 1978). In Indonesian Papua it occurs in Wasur and Lorentz National Parks (Samedi and Iskandar 2000; UNEP-WCMC 2001). Details of the presence of Carettochelys in other protected areas in Papua New Guinea and Indonesian Papua will be important to document, with a view to ensuring adequate protected areas in different portions of its range.

Procedures for egg collection, transportation, and artificial incubation have been established and can be incorporated into management programs with the option of accurately predicting and controlling hatchling sizes, sexes, amounts of internalized yolk and incubation times (Webb et al. 1986). Techniques for accurately aging embryos and for non-destructively assessing the progress of incubation have also been developed (Beggs et al. 2000).

Conservation Measures Proposed. - Given available information, the listing of Carettochelys on CITES Appendix II and the declaration of the species as Vulnerable in the IUCN Red List of Threatened Species would appear to be appropriate. While these listings have some influence on international trade, domestic pressures both within Australia and in New Guinea continue.

Listing of the species as Vulnerable under Australia's EPBC Act would seem appropriate. Such listing would ensure that any development likely to lead to deterioration in population status would trigger the provisions of the Act and give effect domestically to the great international concerns for this species. At the same time, improvements in the coverage of protected areas spanning important parts of the species' range are highly desirable. There are moves to extend formal reserve systems to ensure adequate protection of biodiversity as agricultural development in the catchment proceeds. A Daly basin conservation plan has been drafted, and the feasibility of establishing new parks is being explored, including extending the Flora River Park, establishing reserves at Depot Creek and Fish River, and selecting a representative of the limestone landforms for protection (Northern Territory Parks and Conservation 2005). These developments are of considerable interest 
to indigenous communities within the Daly Catchment (Jackson 2004). One can anticipate substantial benefits for Carettochelys if the ecological integrity of the Daly River and associated riparian zones and wetlands can be protected.

In view of the importance of Carettochelys as a food source for local people and the decentralized nature of the wildlife management authority in Papua New Guinea, any conservation measures need to be introduced with sensitivity (Stubbs 1989). There have been calls for the introduction of a scheme to protect nest sites against over-exploitation, perhaps allied to a closed season for hunting and egg collecting. However, firm data on trends in population numbers and levels of exploitation of Carettochelys for meat and eggs that could be used in support of these calls are lacking.

Preliminary research has established the need for the several measures in Papua New Guinea (Stubbs 1989). First, there is a need for comparative studies on the impact of different levels of exploitation of this species to serve as a foundation for future monitoring of the turtle populations and to enable future advice to be given to local communities to help them protect Carettochelys and its eggs. Second, an assessment of the current intensity of exploitation is required to provide a basis for monitoring, and if necessary, controlling future trends in exploitation with changes in human populations and practices. Third, knowledge of the principal habitat requirements of Carettochelys is required to evaluate and respond to the potential impact of proposed or potential projects in river catchments, such as hydroelectricity schemes, mangrove clearing, wood chipping, etc. Finally, population data are required to determine whether a management program for ensuring a sustainable harvest of Carettochelys is necessary and attainable. These population studies must be associated with research into the possibility of integrating a sustainable harvest system into local economies. This will almost certainly need to be backed up with a public awareness and education campaign. The program should also include provision for training local wildlife staff and maintaining their operations.

Public awareness can be achieved by engaging the community in long-term surveys together with local schools and organizations. The concept of conservation is not fully understood by indigenous people in Papua New Guinea, and could be integrated into their lives through popular methods, such as children's books, plays, and music. Science projects in primary and secondary schools and hatchling-release programs can help to build awareness and training skills not only among students but have the potential to also influence community decisions. One could argue that without a local domestic imperative, externally driven conservation initiatives, however successful in the short-term, will be unsustainable.

There have been several calls for Carettochelys to be given a high priority for funding for research in support of conservation. In view of its restricted range and its importance to the subsistence economy of many native peoples in Papua New Guinea, Pernetta and Burgin (1980) recommended that investigation of the biology and population status of Carettochelys in New Guinea be given high priority. Rose et al. (1982) signaled that the IUCN Specialist Group planned a high priority project on the ecology, reproduction, and economic potential for the longterm management of Carettochelys, as did Stubbs (1989), but no IUCN project has materialized.

Oil Search Ltd., as part of its commitment to the local community and on behalf of its joint venture partners, has funded a number of collaborations to integrate conservation with development. The company recognizes that the social and environmental impacts of any operations can potentially extend well beyond the project area. In entering partnerships with NGOs such as the World Wide Fund for Nature and universities to mitigate these potential impacts, the company and its joint venture partners are breaking new ground. A three-year project on Carettochelys is part of the current portfolio of environmental initiatives funded or otherwise supported by Oil Search and its joint venture partners (Georges et al. 2007a; Georges and Alacs 2007).

Wildlife trade is an ongoing concern that is increasing in priority as more species become threatened through habitat loss and, unlike most pressures, the pressure increases as species decline and their trade becomes more lucrative. Trade is the greatest threat to populations of Carettochelys in Indonesian Papua and to a lesser extent in Papua New Guinea. Identifying the source of traded animals is important to detect 'hotspots' of illegal collection to better direct limited resources to protect populations that are most vulnerable to overexploitation. DNA technologies are ideal for trade monitoring in Carettochelys. Turtles seized by authorities or traded in markets can be sampled non-invasively (e.g. using buccal swabs) and a DNA profile generated to identify their region (i.e. Indonesian Papua versus Papua New Guinea) and even their population of origin. This information can provide evidence for case prosecutions involving Carettochelys. In addition, by identifying 'hotspots' of illegal activity, international conservation and wildlife enforcement agencies (such as CITES) can place greater pressure on local authorities to strengthen enforcement efforts in areas where Carettochelys are collected at unsustainable levels. DNA technologies can be employed to continually monitor the trade activities in these 'hotspot' areas. Curbing the illegal trade is critical for the survival of Carettochelys in the wild, and DNA technologies can greatly contribute by monitoring the illegal trade and providing concrete evidence for convictions.

Indigenous harvest of Carettochelys adults and eggs for local consumption are a significant threat to the survival of wild populations, particularly in Papua New Guinea where they are an important source of protein for the local villagers. The impact of indigenous harvests are of concern because they are likely to be unsustainable (Rose et al. 1982). Mature females are targeted for harvest because they 
are easy to capture during nesting. In addition, almost all nests near settlements are excavated for the highly favored eggs (Eisemberg, unpubl. data). This type of selective harvesting can have significant impacts on many different aspects of the population, including genetics, behavior, life history, and demography over a short ecological time scale, particularly for long-lived species with low fecundity such as Carettochelys (Clark and Tait 1982; Coltman 2008; Fenberg and Roy 2008).

Assessment of what constitutes the target population is critical for management of harvested populations of Carettochelys in Indonesian Papua and Papua New Guinea. Genetic analyses can identify whether the target population is part of a larger network of populations, in which case the impacts of harvesting are spread across a wider area, or if the target population is genetically isolated and highly vulnerable to overexploitation and extinction (Fenberg and Roy 2008). This genetic information can guide the management of these populations to ensure harvests are conducted at sustainable levels. Simple alterations in harvest regimes, such as posing restrictions on the number of nesting females that can be harvested in a given season, can have major impacts on the continued survival of Carettochelys populations in the wild.

Captive Husbandry. - Carettochelys can be readily kept in aquaria in clean water maintained at a temperature between 28 and $33^{\circ} \mathrm{C}$. A seasonal drop in temperature may be necessary to keep gonadal cycles active. A spacious tank with a diversity of underwater cover is required, as even small individuals can become aggressive and will habitually inflict damage to others if confined together. In captivity, they will accept and thrive on a diverse diet of figs, apple, other fruits, eel weed (Vallisneria sp.), whitebait (Osteichthyes) and shrimp. A high pH (7.5-8.5) seems essential for maintaining healthy animals in captivity.

Hatchling and subadult specimens are susceptible to fungal white spot (Sphagnalium sp.) which if not treated promptly, can kill young animals within a week (M. PalmerAllen, pers. comm.). It can be effectively treated externally by removing all loose skin and scabs and treating liberally with $1 \%$ Mercurichrome or Acriflavine solution, which is allowed to dry on the skin before the animals are returned to the tank. Addition of marine salt seems to be effective in preventing fungal infection.

Captive specimens are held in Australia at the Territory Wildlife Park (Darwin), Taronga Park Zoo (Sydney), Sydney Aquarium, the National Aquarium (Canberra), Hartley Creek Crocodile Farm (Cairns), and Australia Zoo (near Nambour). Only the first two organizations are in a position to mount a captive breeding program. Specimens at Territory Wildlife Park mated in 1989 after having been transferred from an outdoor enclosure earlier in the year, and the female subsequently laid eggs on the bottom of the aquarium. Unfortunately, the turtles were removed from this aquarium following damage to the viewing tunnel attributed to their activities, so the possibility of successful breeding in captivity at this facility is now remote. Other instances of captive breeding have been reported for Bronx Zoo (USA), the Zoological Garden Wilhelma, in Stuttgart (Germany), and Rotterdam Zoo (Netherlands), providing potential for this species to be systematically bred in captivity.

Remarks. - An earlier version of this account was first published by Georges and Rose (1993), but has now been extensively updated. Knowledge of the biology of Carettochelys has increased dramatically in the last several years. We know the extent of its distribution, and that it can be locally abundant, but also that it is coming under increasing pressure from human-related activities and that populations are in decline, especially in New Guinea. It has been declared Vulnerable in the IUCN Red List and has recently been listed in CITES Appendix II, but we should be concerned that the trajectory of the conservation status of the species is not stationary nor is it on the upswing. Rather, its status is on a trajectory of continual deterioration which will ultimately lead to Endangered status, by which time many opportunities to act will be lost. More can be done domestically in both Australia and New Guinea to give effect to international concerns, both with regard to legislative protection under the EPBC Act and its equivalents in PNG and Indonesia, and through concrete action on the ground.

Acknowledgments. - We would like to thank the indigenous communities of Arnhem Land, the Daly River, Kakadu, the Suki Aramba region (Fly River), and the Kikori Delta for sharing their traditional knowledge with us and allowing us access to their lands. Much of the information and many of the perspectives presented in this report were grounded in discussions with these communities. Ben Yaru and Oil Search Ltd. provided much logistic support for the work in Papua New Guinea, and the work in Australia that made this report possible and so comprehensive was funded by the Parks and Conservation Commission of the NT, the National Heritage Trust, Environment Australia, CSIRO Sustainable Ecosystems, and the Australian Research Council.

\section{LITERATURE CITED}

AdEs, G.W.J. 2002. Turtle trade monitoring in South China and summary of turtle rescue operation in Hong Kong. Technical workshop on conservation of and trade in freshwater turtles and tortoises in Asia, 25-28 March 2002, Kunming, Yunnan Province (People's Republic of China).

AFP. 2007. Thailand seizes over 1,400 endangered turtles.AFP News Brief, 1 February 2007. Agence-France-Presse, Paris.

Anonymous. 1978. Pendomen Pengelolaan Satwa Langka di Indonesia. Jilid 1: Mammalia, Reptilia dan Amphibia. Direktorat Jenderal Kehutanan (Direktorat Perlindungan dan Pengeawetan Alam). Bogor.

Auliya, M. 2003. Hot trade in cool creatures: a review of the live reptile trade in the European Union in the 1990s with a focus on Germany. TRAFFIC Europe, Brussels, Belgium.

BaILlie, J. AND GRoOMBRIDGe, B. (Eds.) 1996. 1996 IUCN Red List of Threatened Animals. IUCN Gland, Switzerland.

BAur, G. 1891a. The very peculiar tortoise, Carettochelys Ramsay, 
from New Guinea. Science 17:190.

BAUR, G. 1891b. On the relations of Carettochelys, Ramsay. American Naturalist 15:631-639.

Beggs, K., Young, J., Georges, A., And West, P. 2000. Aging the eggs and nests of the pig-nosed turtle Carettochelys insculpta from northern Australia. Canadian Journal of Zoology 78:373-392.

BLANCH, S., REA, N., AND SCOTt, G. 2005. Aquatic conservation values of the Daly River catchment, Northern Territory,Australia.A report prepared by WWF-Australia, Charles Darwin University and the Environment Centre NT. WWF Australia, Darwin.

Boulenger, G.A. 1887. On a new family of pleurodian turtles. Annals and Magazine of Natural History (London), (5)19:461-463.

BOULENGER, G.A. 1898. Exhibition of, and remarks upon, a dancingstick from New Guinea to which two skulls of the chelonian Carettochelys insculpta were attached. Proceedings of the Zoological Society, London 1898(4):851.

BOULENGER,G.A. 1914.An annotated list of the batrachians and reptiles collected by the British Ornithologist's Union expedition and the Wollaston expedition in Dutch New Guinea. Transactions of the Zoological Society, London 20(5):247-268.

Brongersma, L.D. 1958. The Animal World of Netherlands New Guinea. J.B. Wolters, Groningen, 70 pp.

CANN, J. 1972. Notes on some tortoises collected in northern Australia. Victorian Naturalist 89:165-168.

CANN, J. 1974. Collecting in Irian Jaya during 1972. Royal Zoological Society, Bulletin of Herpetology 1(3):4-14.

Cann, J. 1978. Tortoises of Australia. Angus and Robertson, Sydney.

CANN, J. 1980. Confessions of a tortoise freak. Geo 3(2):50-69.

Chaloupka, G., Kapirigi, N., NAYIDJI, B., And Nomingum, G. 1985. Cultural survey of Balawurru, Deaf Adder Creek, Amarrkananga, Cannon Hill and the Northern Corridor. Australian National Parks and Wildlife Service, Canberra.

Chen,B.Y.,MAO,S.H.,ANDLing,Y.H.1980.Evolutionary relationships of turtles suggested by immunological cross-reactivity of albumins. Comparative Biochemistry and Physiology 66B:421-425.

Chen, T.-H., Lin, H.-C., AND Chang, H.-C. 2000. Current status and utilization of chelonians in Taiwan.In: van Dijk,P.P.,Stuart,B.L., and Rhodin, A.G.J. (Eds.). Asian Turtle Trade: Proceedings of a Workshop on Conservation and Trade of Freshwater Turtles and Tortoises in Asia. Chelonian Research Monographs No. 2, pp. 45-51.

ClaRK,C.W. AND TAIT,D.E. 1982. Sex-selective harvesting of wildlife populations. Ecological Modelling 14:251-260.

CogGer, H.G. 1970. First record of the pitted-shelled turtle, Carettochelys insculpta, from Australia. Search 1:41.

Cogger, H.G. 1975. Reptiles and Amphibians of Australia. Angus and Robertson, Sydney.

Cogger, H.G. 2000. Reptiles and Amphibians of Australia. Sixth Edition. Reed New Holland, Sydney: 808 pp.

Cogger, H.G. and Heatwole, H. 1981. The Australian reptiles: origins, biogeography, distribution patterns and island evolution. Monographia Biologicae 41:1331-1373.

Coltman,D.W.2008.Molecularecological approaches to studying the evolutionary impact of selective harvesting in wildlife. Molecular Ecology 17:221-235.

Dames and Moore International. 1987. Coronation Hill Project: Biological Survey of the Coronation Hill area. Final report to BHP Engineering (Job No. 15265-001-073), July 1987.

DAVIES, C.L. 2005. Thermoregulation, activity, and energetics of the pig-nosed turtle (Carettochelys insculpta) in the Daly River, NT. Honours Thesis, Institute for Applied Ecology, University of Canberra, Australia.

DE RooIJ, N. 1915. The reptiles of the Indo-Australian Archipelago I: Lacertilia, Chelonia, Emydosauria. E.J. Brill Ltd, Leiden.

DE Roois, N. 1922. Reptiles (Lacertilia, Chelonia and Emydosauria). Nova Guinea (Zoology) 13:133-153.

Delmas, V., Prevot-Julliard, C., Pieau, C., and Girondot, M. 2008. A mechanistic model of temperature-dependent sex determina- tion in a chelonian: the European pond turtle. Functional Ecology 22:84-93.

DooDy, J.S. 2002. Ecology and sex determination in the pig-nosed turtle in the Australian wet-dry tropics. Ph.D. Thesis, Institute for Applied Ecology, University of Canberra, Australia

DoOdY, J.S. AND GEORGES, A. 2002. A novel technique for gathering emergence and testing phenology data in turtles. Herpetological Review 31:220-222.

Doody, J.S., Georges, A., Pauza, M., Young, J.E., Pepper, A., AND Alderman, R. 2001a. Embryonic aestivation and emergence ecology in the pig-nosed turtles (Carettochelys insculpta) in the wet-dry tropics of Northern Australia. Canadian Journal of Zoology 79:1062-1072.

DoODY,J.S.,Sims, R.A., AND GEORGES,A. 2001b.Use of thermal springs for aquatic basking by the pig-nosed turtle, Carettochelys insculpta. Chelonian Conservation and Biology 4:81-87.

Doody, J.S., Young, J.E., AND Georges, A. 2002. Sex differences in activity and movements in the pig-nosed turtle, Carettochelys insculpta, in the wet-dry tropics of Australia. Copeia 2002:93-103.

Doody, J.S.,Georges,A., AND Young, J.E.2003a. Twice every second year: reproduction in the pig-nosed turtle, Carettochelys insculpta, in the wet-dry tropics of Australia. Journal of Zoology, London 259:179-188.

DoOdY,J.S.,Sims, R.A., AND GEORGES,A. 2003b.Gregarious nesting in pig-nosed turtles (Carettochelys insculpta) doesnotreduce predation risk. Copeia 2003:894-898.

Doody, J.S., West, P., AND Georges, A. 2003c. Beach selection in nesting pig-nosed turtles, Carettochelys insculpta. Journal of Herpetology 37:178-182.

Doody, J.S., Georges, A., AND Young, J.E. 2004. Determinants of reproductive success and offspring sex in a turtle with environmental sex determination. Biological Journal of the Linnean Society, London 80:1-16.

Doody, J.S., Green, B., Sims, R.A., Rhind, D., West, P., AND Steer, D. 2006. Indirect impacts of invasive cane toads (Bufo marinus) on nest survival in pig-nosed turtles (Carettochelys insculpta). Wildlife Research 33:349-354.

Doody, J.S.,GreEn, B., Sims, R.A., AND RHIND, D. 2007.Apreliminary assessment of the impacts of invasive cane toads (Bufo marinus) on three species of varanid lizards in Australia. Mertensiella 3:218-227.

Dupe, K.V. 1980. The pitted shelled turtle Carettochelys insculpta in the Northern Territory. Northern Territory Naturalist 1:14.

ERBEN, H.K. 1970. Ultrastrukturen und mineralisation rezenter und fossiler Eischalen bei Vogeln und Reptilien. Biomineralization $1: 1-66$.

Erskine, W.D., BegG, G.W., Jolly, P., Georges, A., O’Grady, A., Eamus, D., Rea, N., Dostine, P., Townsend, S., and Padovan, A. 2003. Recommended environmental water requirements for the Daly River, Northern Territory, based on ecological, hydrological and biological principles. Report 175, National River Health Program, Environmental Flows Initiative. Office of the Supervising Scientist, Darwin NT.

FenBERG, P.B. AND Roy, K. 2008. Ecological and evolutionary consequences of size-selective harvesting: how much do we know? Molecular Ecology 17:209-220.

FidRUs, M. 2004. Officers save protected turtles. The Jakarta Post, Indonesia, 2 March 2004.

FRAIR, W. 1983. Serological survey of softshells with other turtles. Journal of Herpetology 17:75-79.

FRAIR, W. 1985. The enigmatic plateless river turtle, Carettochelys, in serological survey. Journal of Herpetology 19:515-523.

FREELAND, W.J. AND Boulton, W.J. 1990. Feral water buffalo (Bubalus bubalis) in the major floodplains of the Top End, Northern Territory, Australia: Population growth, and the Brucellosis and Tuberculosis Eradication Campaign. Australian Wildlife Research 17:411-420.

FuJtTA,M.K.,ENGSTROM,T.N.,STARKEy,D.E.,ANDSHAFFER,H.B. 2004. Turtle phylogeny: insights from a novel nuclear intron. Molecular 
Phylogenetics and Evolution 31:1031-1040.

GADOw, H. 1901. Amphibia and Reptiles. Macmillan and Co., London.: 668 pp.

GeORGES,A.1987.The pig-nosedturtle-warradjan. Australian Natural History 22:230-234.

Georges, A. 1989. Female turtles from hot nests: is it amount of development or duration of incubation at high temperatures that matters? Oecologia (Berlin) 81:323-328.

GEORGES, A. 1992. Thermal characteristics and sex determination in field nests of the pig-nosed turtle,Carettochelysinsculpta (Chelonia: Carettochelydidae), from northern Australia. Australian Journal of Zoology 40:511-521.

GeOrges, A. and Alacs,E.A. 2007. The pig-nosed turtle in the Kikori: options for research to support conservation and management. Report to Oil Search Ltd, Sydney, February 2007. Institute for Applied Ecology, University of Canberra., Australia.

Georges, A. And Kennett, R. 1988. Dry-season distribution and ecology of the Warradjan (Carettochelys insculpta Ramsay) in Kakadu National Park. Canberra, Report to the Australian Nature Conservation Agency, $62 \mathrm{pp}$.

Georges, A. And Kennett, R. 1989. Dry-season distribution and ecology of Carettochelys insculpta (Chelonia: Carettochelydidae) in Kakadu National Park, northern Australia. Australian Wildlife Research 16:323-335.

Georges, A. And Rose, M. 1993. Conservation biology of the pignosed turtle, Carettochelys insculpta. Chelonian Conservation and Biology 1(1):3-12.

Georges, A. And Wombey, J. 1993. Family Carettochelyidae. In: Godsell,J.(Ed.). Fauna of Australia, Volume 2: Amphibia, Reptilia, Aves. Australian Biological Resources Study, DASETT, Canberra, pp. 153-156.

Georges, A., Choquenot, D., Coventry, A.J., And Wellings, P. 1989. A note on Carettochelys insculpta (Testudinata: Carettochelyidae) from northern Australia. Northern Territory Naturalist 11:8-11.

Georges, A., Limpus, C.J., And StoutjesdiJK, R. 1994. Proportion of development at a temperature, not daily duration of exposure, determines sex in the marine turtle Caretta caretta. Journal of Experimental Zoology 270:432-444.

Georges, A., Webster, I., Guarino, E., Thoms, M., Jolley, P., And Doody, J.S. 2002. National River Health Program: modelling dry season flows and predicting the impact of water extraction on a flagship species. Department of Lands, Planning and Environment, NT., Canberra: 73 pp.

Georges,A.,Doody,J.S.,BegGs,K., ANd Young,J.2004.Thermal models of TSD under laboratory and field conditions. In: Valenzuela, N. and Lance, V.(Eds.). Temperature Dependent Sex Determination in Reptiles. Smithsonian Institution Press, Washington, pp. 79-89.

Georges, A., Beggs, K., Young, J.E., And Doody, J.S. 2005. Modelling reptilian development under fluctuating temperature regimes. Physiological and Biochemical Zoology 78:18-30.

Georges, A., Guarino, F., And Bito, B. 2006. Freshwater turtles of the TransFly Region of Papua New Guinea - notes on diversity, distribution, reproduction, harvest and trade. Wildlife Research 33:373-384.

GeOrges, A.,Alacs, E.A., AND KinginaPI, F. 2007a.Freshwater turtles of the Kikori, with special reference to the pig-nosed turtle. Report to Oil Search Ltd and WWF (PNG). Institute for Applied Ecology, University of Canberra, Australia: $46 \mathrm{pp}$.

Georges, A., Alacs, E.A., AND KinginaPI, F. 2007b. Freshwater turtles of the Kikori (with special reference to the pig-nosed turtle). Report to Oilsearch Pty Ltd, Sydney and World Wide Fund for Nature (WWF), by the Institute for Applied Ecology, University of Canberra. January 2007.

Georges, A., Alacs, E.A., Pauza, M., Kinginapi, F., Ona, A., AND EISEMBERG, C. 2008. Freshwater turtles of the Kikori Drainage, Papua New Guinea, with special reference to the pig-nosed turtle, Carettochelys insculpta. Wildlife Research 2008: in press.

GoH,T.Y.ANDO'RioRDAN,R.M.2007.Areturtles and freshwaterturtles still traded illegally as pets in Singapore? Oryx 41:97-100.

HARSAPUTRA, I. 2005. BKSDA officials rescue protected turtles. The Jakarta Post, Indonesia, 16 March 2005.

HaY, O.P. 1908. The Fossil Turtles of North America. Carnegie Institute, Washington.

HEAPHY, J.L. 1990. The ecology of the pig-nosed turtle Carettochelys insculpta, in northern Australia. Ph.D. Thesis, Department of Zoology, University of New South Wales, Sydney.

Herington, J.G. 1978. Wildlife Management Areas in Papua New Guinea. 2. Tonda. Wildlife in Papua New Guinea 78(10):1-27.

IUCN. 2007. The 2007 IUCN Red List of Threatened Species. The World Conservation Union, Gland, Switzerland. http://www. iucnredlist.org.

IVERSON,J.B. 1992.ARevised Checklist with Distribution Maps of the Turtles of the World. Richmond, IN: Privately printed, $363 \mathrm{pp}$.

JACKSON, S. 2004. Preliminary report on Aboriginal perspectives on land-use and water management in the Daly River region of the Northern Territory. Report to the Northern Land Council by CSIRO Sustainable Ecosystems, Canberra.

Kameoka,S. And Kiyono,H. 2005. Japan's Trade in Live Tortoises and Freshwater Turtles as Pets. [in Japanese with English summary]. TRAFFIC, East Asia and Japan, 43 pp.

LEGLER, J.M. 1980. Taxonomy, distribution and ecology of freshwater turtles in the Alligator Rivers region, Northern Territory. Open File Record 2,12-Sep-1980 (Supplementary Report 1-Jul-1982). Office of the Supervising Scientist, Darwin.

LEGLER, J.M. 1982. The ecology of freshwater turtles in the Alligator Rivers region. Open File Record 66, September 1982. Office of the Supervising Scientist, Darwin.

LIEM, D.S. 1977. Important wildlife species of the Tonda Wildlife Management Area of the Western Province. Wildlife in Papua New Guinea 77(20):1-7.

LIEM, D.S. AND HAINES, A.K. 1977. The ecological significance and economic importance of the mangrove and estuarine communities of the Gulf Province, Papua New Guinea, Purari River (Wabo) Hydroelectric Scheme Environmental Study. 3:1-35.

Longman, H.A. 1913. Herpetological notes. Part I. - Systematic. Including the description of one new species. Memoirs of the Queensland Museum 2:39-45.

Maturbongs, J.A. 2001. Trade monitoring of pig nose turtle (Carettochelys insculpta) from Vriendschap River, District of Suator, Merauke Regency, Irian Jaya. In: Noerdjito, M. and Maryanto, I., Eds). Jenis-jenis Hayati yang Dilindungi Perundangundangan Indonesia. Lembaga Ilmu Pengetahuan Indonesia (LIPI) and The Nature Conservancy, Cibinong, Indonesia: pp. 21-27.

Meylan, P.A. 1988. Peltochelys Dollo and the relationships among the genera ofCarettochelyidae (Testudines:Reptilia).Herpetologica 44:440-450.

NTPC. 2005. Draft Territory Parks and Conservation Master Plan, Edition 7, December 2005. Northern Territory Parks Commission, Department of Natural Resources, Environment and the Arts, Palmerston, NT.

OGILBY, J.D. 1890. Description of a new Australian tortoise. Records of the Australian Museum 1:56-59.

Pernetta, J.C. And Burgin, S. 1980. Census of crocodile populations and their exploitation in the Purari area (with an annotated checklist of the herpetofauna). Purari River (Wabo) Hydroelectric Scheme Environmental Study 14:1-44.

Peters, U. 1970. Die Papua-Schildkrote (Carettochelys insculpta) in Australien! Aquarien und Terrarien-Zeitschrift (Stuttgart) 23:182-183.

PRESS,A.J.1986.The Gagudju species survey.Canberra,Unpubl.report to the Australian National Parks and Wildlife Service.

PRITCHARD, P.C.H. 1979a. Encyclopedia of Turtles. TFH Publications, New Jersey.

PRITCHARD, P.C.H. 1979b. Taxonomy, evolution, and zoogeography. In: Harless, M. and Morlock, H. (Eds.). Turtles: Perspectives and Research. John Wiley, New York: pp. 1-42. 
Rabinowitz, D. 1981. Seven forms of rarity. In: Synge, H. (Ed.). The Biological aspects of rare plant conservation. Wiley, New York: pp. 205-217.

RAMSAY, E.P. 1886. On a new genus and species of fresh water turtle from the Fly River,New Guinea.Proceedings of the Linnean Society of New South Wales 1:158-162.

Rhodin, A.G.J. AND Genorupa, V.R. 2000. Conservation status of freshwater turtles in Papua New Guinea. In: van Dijk, P.P., Stuart, B.L., and Rhodin, A.G.J. (Eds.). Asian Turtle Trade: Proceedings of a Workshop on Conservation and Trade of Freshwater Turtles and Tortoises in Asia. Chelonian Research Monographs No. 2, pp. 129-136.

RHodin, A.G.J. AND RHodin, S.D. 1977. Observations from a herpetological collecting trip to Papua New Guinea [in Swedish with English summary]. Snoken (National Swedish Herpetological Society) 7(2/3):65-72.

Rose, M.R. 1981. Draft Red Data Book account of Carettochelys insculpta.IUCN/SSC Specialist Group on Tortoises and Freshwater Turtles, Gland.

Rose, M.R., Parker, F., and Rhodin, A.G.J. 1982. New Guinea plateless turtle or pitted shell turtle (Fly River or pig-nosed turtle), Carettochelys insculpta Ramsay 1886. In: Groombridge, B. (Ed.). The IUCN Amphibia-Reptilia Red Data Book, Part 1. Testudines, Crocodylia, Rhynchocephalia. Gland: International Union for Conservation of Nature and Natural Resources, pp. 243-246.

SAMEDI AND IRVAN. 2002. Utilization and Trade in Freshwater Turtles and Tortoises in Indonesia. Technical Workshop on Conservation of and Trade in Freshwater Turtles and Tortortoises in Asia, Kunming, Yannan Province, Peoples Republic of China.

SAMEDI AND IsKandar, D.T. 2000. Freshwater turtle and tortoise conservation and utilization in Indonesia. In: van Dijk, P.P., Stuart, B.L., and Rhodin, A.G.J. (Eds.). Asian Turtle Trade: Proceedings of a Workshop on Conservation and Trade of Freshwater Turtles and Tortoises in Asia. Chelonian Research Monographs No. 2, pp. 106-111.

Schodde, R., Mason, I., AND Wolfe, T.O. 1972. Further records of the pitted- shelled turtle (Carettochelys insculpta) from Australia. Transactions of the Royal Society of South Australia 96:115-117.

Schultze-Westrum, T. 1963. Die Papuaschildkröte aus Neuguinea. Natur und Museum, Frankfurt 93(4):119-127.

Shaffer, H.B., Meylan, P., and McKnight, M.L. 1997. Tests of turtle phylogeny: molecular, morphological, and paleontological approaches. Systematic Biology 46:235-268.

SHEPHERD, C.R. AND NIJMAN, V. 2007. An overview of the regulation of the freshwater turtle and tortoise pet trade in Jakarta, Indonesia. TRAFFIC, Southeast Asia, Petaling Jaya, Malaysia, 136 pp.

Simpson, G.G. 1944. Tempo and Mode in Evolution. Columbia University Press, New York.

Slater, K.R. 1961. Reptiles in New Guinea. Australian Territories 1(5):27-35.

STRAUCH, A. 1890. Bemerkungen über die Schildkrötensammlung im Zoologischen Museum der kaiserlichen Akademie der Wissenschaften zu St. Petersburg. Mémoires de l'Académie Impériale des Sciences de St.-Pétersbourg (7)38(2):1-127.

StuBBs, D. 1989. Tortoises and freshwater turtles - an action plan for their conservation. IUCN/SSC Tortoise and Freshwater Turtle Specialist Group, 48 pp.

TSSC.2005.Pig-nosed Turtle (Carettochelys insculpta).Advice to the
Minister for the Environment and Heritage on amendments to the list of Threatened Species under the Environment Protection and Biodiversity Conservation Act 1999, 13 July 2005.

UNEP-WCMC. 2001. Protected Areas and World Heritage [Lorentz National Park]. http://www.unep-wcmc.org/sites/wh/lorentz.html

U.S.FISH ANDWILDLIFESERVICE. 2003. Singapore man sentenced toover three years in jail for illegally smuggling wildlife. Press Release. 11 December 2003. http://www.fws.gov/southeast/news/2003/ r03-140.html.

VAILLANT,L. 1894.Essai sur la classification générale des chéloniens. Annales des Sciences Naturelles, Paris 16:331-345.

van DiJk, P.P., IsKandar, D.T., PaLASUWAN, T., Rhodin,A.G.J., SAMEdi, Sharma, D.S.K., ShePherd, C.R., Tisen, O.B., and GenoruPa, V.R. 2000. Turtle trade in southeast Asia: regional summary (Indonesia, Malaysia, Papua New Guinea, and Thailand). In: van Dijk, P.P., Stuart, B.L., and Rhodin, A.G.J. (Eds.). Asian Turtle Trade: Proceedings of a Workshop on Conservation and Trade of Freshwater Turtles and Tortoises in Asia. Chelonian Research Monographs No. 2, pp. 145-147.

WAITE, E.R. 1905. The osteology of the New Guinea turtle (Carettochelys insculpta, Ramsay). Records of the Australian Museum 6:110-118.

Walther, W.G. 1922. Die Neu-Guinea-Schildkrote Carettochelys insculpta Ramsay. Nova Guinea (Zoology) 13:607-704.

Webi, G.J.W., Choquenot, D., And Whitehead, P. 1986. Nests, eggs and embryonic development of Carettochelys insculpta (Chelonia: Carettochelidae) from northern Australia. Journal of Zoology, London 1B:512-550.

WeLLS,R.W.2002.Anew subspecies of Carettochelys (Reptilia: Carettochelydidae) from northern Australia - Carettochelys insculpta canni ssp. nov. Australian Biodiversity Record 2002(1):1-7.

WELSH, M. 1999. Resource partitioning among the freshwater turtles of the Daly River, Northern Territory. Honours Thesis, Institute for Applied Ecology, University of Canberra, Australia.

Wermuth, H. 1963. Die Papua-Weichschildkrote, Carettochelys insculpta Ramsay. Aquarien und Terrarien-Zeitschrift (Stuttgart) 16:341-343.

WiLLIAMs, E.E. 1950. Variation and selection in the cervical central articulations of living turtles. Bulletin of the American Museum of Natural History 94:505-562.

YNTEMA, C.L. 1968. A series of stages in the embryonic development of Chelydra serpentina. Journal of Morphology 125:219-252.

Young, J.E., Georges, A., Doody, J.S., West, P.B., AND Alderman, R.L. 2004. Pivotal range and thermosensitive period of the pig-nosed turtle,Carettochelysinsculpta (Testudines:Carettochelydidae),from northern Australia. Canadian Journal of Zoology 82:1251-1257.

\section{Citation Format for this Account:}

Georges, A., Doody, J.S., Eisemberg, C., Alacs, E.A., and Rose, M. 2008. Carettochelys insculpta Ramsay 1886 - pig-nosed turtle, Fly River turtle. In: Rhodin, A.G.J., Pritchard, P.C.H., van Dijk, P.P., Saumure, R.A., Buhlmann, K.A., and Iverson, J.B. (Eds.). Conservation Biology of Freshwater Turtles and Tortoises: A Compilation Project of the IUCN/SSC Tortoise and Freshwater Turtle Specialist Group. Chelonian Research Monographs No. 5, pp. 009.1-009.17, doi:10.3854/crm.5.009. insculpta.v1.2008, http://www.iucn-tftsg.org/cbftt. 